\title{
Land-sea correlations in the Australian region: 460 ka of changes recorded in a deep-sea core offshore Tasmania. Part 2: the marine compared with the terrestrial record
}

Patrick De Deckker ${ }^{a^{*}}$, Timothy T. Barrows ${ }^{b, c}$, Jan-Berend Stuutd ${ }^{d, e}$, Sander van der Kaars ${ }^{f, g}$, Michael A. Ayress $^{h}$, John Rogers ${ }^{a}$, and George Chapronierei,

a Research School of Earth Sciences, The Australian National University, Acton, ACT 2601, Australia; b School of Earth and Environmental Sciences, University of Wollongong, NSW 2522, Australia; c.Department of Geography, University of Portsmouth, PO1 2UP. UK; d NIOZ, Royal Netherlands Institute for Sea Research, Dept. of Ocean Systems, and Utrecht University, Landsdiep 4, 1797 SZ Den Hoorn, Texel, The Netherlands; e MARUM, Center for Marine Environmental Sciences, University of Bremen, Leobenerstrasse 8, Bremen, D-28359 Germany; ${ }^{f}$ School of Earth, Atmosphere and Environment, Monash University, Monash University, Clayton VIC 3800, Australia; g Cluster Earth \& Climate, Faculty of Earth and Life Sciences, Vrije Universiteit, 1081 HV Amsterdam, Netherlands; $g$ RPS Ichron Ltd, Century House, Gadbrook Business Centre, Northwich, Cheshire CW9 7TL, UK; । Formerly of the Department of Earth and Marine Sciences, The Australian National University, Canberra, ACT 2601, Australia

CONTACT P. De Deckker E-mail address: patrick.dedeckker@anu.edu.au

Received 19 December 2017; accepted 24 June 2018

Editorial handling: Dioni Cendon

This manuscript is the final submitted version and contains errors that were corrected during proofing. To access the published version, please see:

https://doi.org/10.1080/08120099.2018.1495100 


\section{Abstract}

We present an array of new proxy data and review existing ones from core Fr1/94-GC3 from the East Tasman Plateau. This core is positioned at the southern extreme of the East Australia Current and simultaneously records changes in both oceanography and environments both offshore and in southeastern Australia. Microfossils, including planktonic and benthic foraminifera, ostracods, coccoliths, and radiolarians, were studied to interpret paleo-oceanographic changes. Sea-surface temperature was estimated using planktonic foraminifera, alkenones and radiolaria. From the silicate sediment fraction, the mean grain size of quartz grains was measured to detect changes in wind strength. An XRF scan of the entire core was used to determine the elemental composition to identify provenance of the sediment. We also compare these data with a pollen record from the same core provided in an accompanying paper that provides the longest well-dated record of vegetation change in southeastern Australia.

In an area of slow sedimentation, Fr1/94-GC3 provides a continuous record of change in southeastern Australia and the southern Tasman Sea over approximately the last $460 \mathrm{ka}$. We determine that the East Australian Current varied in intensity through time and did not reach the core site during glacial periods but was present east of Tasmania during all interglacial periods. The four glacial-interglacial periods recorded at the site vary distinctly in character with Marine Isotope Stage (MIS) 9 being the warmest and MIS 5 the longest. Through time, glacial periods have progressively become warmer and shorter. Deposition of airborne dust at the core site is more substantial during interglacial periods than glacials and is believed to derive from mainland Australia and not Tasmania. It is likely that the source and direction of the dust plume varied significantly with the wind regimes between glacials and interglacials as mean effective precipitation changed.

KEYWORDS: airborne dust, alkenone temperature, coccoliths, foraminifera transfer function, seasurface temperature, westerlies

\section{Introduction}

The benthic foraminifera $\delta^{18} \mathrm{O}$ record shows that the Quaternary Period is characterised by climatic cycles resulting from sea-level changes associated with ice-sheet fluctuations. These fluctuations, commonly referred to as Milankovitch cycles, have long been recognised as being linked to orbital frequencies (Hays, Imbrie, \& Shackleton, 1976). Superimposed on the isotopic sea-level record are local variations resulting from oceanic temperature changes also recorded in Antarctic ice cores (e.g., EPICA Community Members, 2004). When we examine these long records in detail, each glacial cycle is different. It is therefore important to understand the regional differences in these changes. By studying records from both land and ocean, it is possible to identify patterns of change across the land-ocean climatic system and the climatic response of the Earth between glacial cycles. Long and continuous climatic records are rare on most continents because glaciers or erosion prevented the build-up of long and continuous sediment archives. Australia, for example, does not have long and continuous records in lacustrine deposits, mainly because sediment deflation and the migration of depocentres in lake basins have resulted in discontinuous preservation. For depositional shifts, refer to Lake Frome in South Australia (Bowler, 1986); for gaps due to deflation and pedogenesis, refer to Lake George in New South Wales (Singh \& Geissler, 1985); for gaps due to 
deflation and long dry periods refer to Kati Thanda-Lake Eyre (Alley, 1998; Magee, Miller, Spooner, \& Questiaux, 2004). Long records are also very difficult to date, and recently techniques such as OSL, ESR, and tephrochronology on lacustrine sediments have helped date sequences beyond the limit of radiocarbon. Consequently, the logical approach to recover long records has been to study marine records that can be dated using a standard oxygen isotope stratigraphy.

This paper presents a study on a deep-sea core that contains a range of climatic and oceanographic proxies that will allow us to study the response of a climatic system over several glacial cycles. Our approach has been to study as many proxies as possible that can provide information on changes on land, such as rainfall, wind regimes (including wind strength via grain size), and airborne dust (via the deposition of terrigenous clays in cores recognised by XRF scanning of the cores). In addition, in the companion paper of De Deckker, van der Kaars, Macphail, \& Hope (2019), we also obtained land temperatures using pollen transfer functions. All these proxies can then be linked to conditions in the ocean-atmosphere system via the standard set of proxies already applied to marine cores (such as sea-surface temperature obtained from alkenones and planktic foraminifera). These, in combination with other paleo-oceanographic proxies, provide information on conditions in the water column and the movement of water masses, currents and frontal systems.

\section{Modern oceanographic and meteorological setting}

The southwestern Tasman Sea is characterised by both abyssal plains (>4000 m) and a very narrow continental shelf (on average just a few $\mathrm{km}$ wide). Biogenic carbonates are therefore rare and, consequently, carbonate sequences from the East Tasman Plateau and the South Tasman Rise (Figure 1) have been targeted for deep-sea coring (Hiramatsu \& De Deckker, 1997a; Martinez, 1994; Nees, 1997; Nees, Martinez, De Deckker, \& Ayress, 1994; Nürnberg \& Groenveld, 2006; Nürnberg, Brughmans, Schönfeld, Ninnemann, \& Dullo, 2004). All these studies have already shown the possibility of extracting much information detailing paleo-oceanographical changes in the region. At the sea surface, the poleward East Australia Current (EAC), which originates in the Coral Sea, follows the Australian coastline. It is a western boundary current that transports about 15 Sverdrup (Sv $\left.=1 \times 10^{6} \mathrm{~m}^{3} / \mathrm{s}\right)$ (Tomczak \& Godfrey, 2003) and is associated with significant surface instabilities. This warm current gained intensity during the austral summer and, at that time, the EAC can travel as far as eastern Tasmania and may even flow on side of the island as the Tasman Outflow (see Figure 1) (Ridgway, 2007; Ridgway \& Hill, 2009). The EAC bifurcates at around $32-34^{\circ} \mathrm{S}$ to form the Tasman Front (TF) that reaches the northern tip of New Zealand. It forms a boundary between the warm waters of the Coral Sea and the cold surface waters from the southern portion of the Tasman Sea. The divergence causes significant eddies that can travel further south, clearly visible in false colour satellite images. These eddies can extend to considerable depths (up to $500 \mathrm{~m}$; see Tomczak \& Godfrey, 2003) and can transport tropical organisms into colder waters (Feary et al., 2014), sometimes generating plankton blooms visible from space (Supplementary papers, Figure S1). The Subtropical Front (STF), also called the Subtropical Convergence, passes south of Tasmania and defines the boundary between the Tasman Sea and the Southern Ocean (Belkin \& Gordon, 1996). The STF marks the boundary between warm, salty, subtropical waters to the north and cool, less saline, waters from the Southern Ocean. Previously, several authors (Barrows et al., 2007; Kawagata, 2001; Kawahata, 2002; Martinez, 1994) have indicated that both the STF and the TF shifted northward 
during glacial episodes. South of the STF is the westerly wind zone. It is important to note that during low sea levels, the shallow Bass Strait would have been exposed as the Bassian Plain and westerlies probably varied in strength and latitude. Of great importance to both the position of the oceanic fronts south of Australia as well as for climates on the southern part of the continent are the westerly winds. Shulmeister et al. (2004) have already well documented that the Southern Hemisphere westerlies waxed and waned on numerous occasions at least during the last two glacial/interglacial cycles. This was particularly important during the Last Glacial Maximum when the westerlies were close to Australia as shown by De Deckker, Moros, Perner and Jansen (2012) near Kangaroo Island. In addition, Hesse, Magee and van der Kaars (2004) discussed the implications of strong westerlies and arid conditions on the Australian mainland.

Rochford (1957) identified various water masses at the surface: the Central Tasman Water $\left(15-20^{\circ} \mathrm{C}\right.$ and in practical salinity units [PSU] $35.5-35.7)$, the South-west Tasman Water (SWTW) $\left(12-15^{\circ} \mathrm{C}\right.$, 35.25-35.4 PSU), and the North Bass Strait Water (NBSW) (12-15 $\left.{ }^{\circ} \mathrm{C}, 35.5-35.7 \mathrm{PSU}\right)$ which is more saline than the SWTW due to evaporation. The NBSW eventually 'cascades' down the Bass Canyon to dissipate northward into the Tasman Sea and is commonly referred to as a "Meddy", being similar to water cascading through the Gibraltar Strait into the Atlantic Ocean (Luick, Käse, \& Tomczak, 1994). At depth, the Subantarctic Intermediate Water, a mass lying between 200 and $500 \mathrm{~m}$, has a lower salinity range (34.6-35.2 PSU) than the surface waters, and sits above the Antarctic Intermediate Water which can extend down to $\sim 1100 \mathrm{~m}$ and has an even lower salinity range (34.3734.53 PSU). The Deep Water mass extends down to $\sim 3000 \mathrm{~m}$ and has a salinity of 34.74 PSU (Supplementary papers, Figure S2). Around the Tasman Plateau, the modern thermocline is at $\sim 200$ $\mathrm{m}$ water depth and the waters are depleted in silica and nitrate in the upper $100 \mathrm{~m}$ of the water column due to biological activity. For more information on seasonal changes of the various water masses within the upper $500 \mathrm{~m}$ of the water column, with respect to temperature, salinity, silica, nitrate and phosphate near the core site see Supplementary papers (Figure S3).

Australia is constantly traversed on a 5-6-day basis, both in winter and summer, by anticyclones (cold fronts) (Gentilli, 1971). These depressions develop in major frontal regions between subtropical and polar air masses (Sturman \& Tapper, 1996), mostly over the Southern Ocean, south of Australia and New Zealand (see Supplementary papers, Figure S4). Ahead of these fronts, there is often a northern dust cloud, originating in the interior of Australia, some of which will end up in the Tasman Sea and even travel as far as New Zealand onto New Zealand glaciers (Marx, Kamber, \& McGowan, 2005). Some of the fronts are extremely cold and carry moisture that will generate rain over the southern portion of the continent including Tasmania. It is critical to this study to know that any front moving across southern Australia (from west to east) will typically contribute to a flow of air moving perpendicular to the front, and that, frequently, this air mass will carry dust uplifted as the front passes through. Thus Australian continental dust can reach Tasmania and the surrounding seas. For further details, refer to De Deckker et al. (2014, figure 12).

\section{Previous paleoceanographic investigations on the East Tasman Rise}

This paper centres on the study of core Fr1-94-GC3 (hereafter referred to as GC3). This core was obtained in January 1994 by the RV Franklin using a gravity corer at a depth of $2667 \mathrm{~m}$ at $44^{\circ} 15.38^{\prime} \mathrm{S}$, 
$149^{\circ} 59.47^{\prime} \mathrm{E}$ (Figures 1 and 2 ). It is $4.71 \mathrm{~m}$ long and is almost uniformly olive grey clay (5Y $5 / 1$ to $6 / 2$ ). The coarse [>150 $\mu \mathrm{m}]$ fraction consists almost entirely of biogenic carbonates.

GC3 has previously been investigated by a number of researchers. Hiramatsu and De Deckker (1997a) examined the distribution of the calcareous nannoplankton at $5 \mathrm{~cm}$ intervals for the entire core. In order to obtain an age model for the entire core, oxygen isotope analyses were performed on samples consisting of the planktic foraminifer Globigerina bulloides taken at the same intervals as the coccolith samples. The core was found to span the last $460 \mathrm{ka}$, representing four glacial-interglacial cycles. Nees (1997) studied the benthic foraminiferal composition at $5 \mathrm{~cm}$ intervals for the upper 160.5 $\mathrm{cm}$. Calvo, Pelejero, Logan, \& De Deckker (2004) and Pelejero et al. (2009) examined the presence of molecular biomarkers in samples at $5 \mathrm{~cm}$ intervals and used alkenones in the same samples to reconstruct sea-surface temperatures (SST). In addition, Nees et al. (1994) described the benthic foraminiferal composition of a nearby $5.50 \mathrm{~m}$ long Eltanin core, E36-23, taken at a depth of $2566 \mathrm{~m}$ and located at $43^{\circ} 53^{\prime} \mathrm{S}, 150^{\circ} 03^{\prime} \mathrm{E}$, at $5 \mathrm{~cm}$ intervals. Nees et al. (1997) studied the benthic foraminifera and diatoms for the last two glacial/interglacial cycles in core MD88-779 located on the South Tasman Rise and showed that there is an absence of diatoms during glacial periods, despite evidence of high oceanic productivity indicated by the benthic foraminifera. These authors also suggested that diatom frustules must have been dissolved during those periods. They also postulated a northward shift of both the Subtropical and Subantarctic Fronts near the core site during the cold periods.

Further east, Kawagata (1999) investigated the benthic foraminifera record from three cores in the central Tasman Sea, but only one, NGC98 (34⒌ $59.9^{\prime} \mathrm{S}, 162^{\circ} 30.6^{\prime} \mathrm{E}$, depth $1338 \mathrm{~m}$ ), is of interest here, as is located in the south-central part of the Tasman Sea below the path of the Tasman Front. In a subsequent paper Kawagata (2001) discussed in detail the benthic foraminifera and associated paleooceanographic changes spanning the last $250 \mathrm{ka}$.

Kawahata (2002) identified shifts in oceanic and atmospheric boundaries from four cores taken in the central Tasman Sea: the core analysed by Kawagata (1999) and an adjacent core NGC 97

$\left(35^{\circ} 29.97^{\prime} \mathrm{S}, 160^{\circ} 59.90^{\prime} \mathrm{E}\right.$, depth $\left.3166 \mathrm{~m}\right)$, which spans the last $220 \mathrm{ka}$, and two others located much further north in the Tasman Sea.

Hesse (1994) examined the record of continental dust from Australia in the Tasman Sea half way between Australia and New Zealand.

\section{Methods}

De Deckker et al. (2019) documents how the core was processed and sampled and provides all the information on the core stratigraphy and stable-isotope analyses of foraminifera. A micro-splitter was used to produce final samples containing about 350-400 foraminifera. The planktic foraminifera were identified and counted by T. T. Barrows (the upper $150 \mathrm{~cm}$ ) and G. Chaproniere (to the bottom of the core). The taxonomy of the planktic foraminifera follows the classification of Saito, Thompson and Berger (1981). The micro-splitter was also used to obtain representative portions of each of the original samples for the foraminifera isotopic analyses. M. J. Ayress extracted, identified and counted benthic ostracods from the samples from the $>150 \mu \mathrm{m}$ fraction for the upper $220.5 \mathrm{~cm}$.

Up to 30 single individual tests of the planktic foraminifera Globigerina bulloides (size range 300-350 $\mu \mathrm{m}$ ) were used for stable isotope analysis carried out at the Research School of Earth Sciences at the ANU using a Finnigan MAT 251 mass spectrometer with an automate acid-on-sample carbonate Kiel device. 
Sample reaction was carried out at $90^{\circ} \mathrm{C}$. The NBS-19 standard was also run to provide checks against drift and results were corrected to the Pee Dee belemnite standard (VPDB). Samples were run by Mr J. Cali. Additional samples for benthic isotope analysis were taken by $\operatorname{Dr} A$. Sturm and his analyses for $\delta^{18} \mathrm{O}$ were performed at Kiel University on a Finnigan MAT 252 mass spectrometer with a Kiel CARBON II device. On average 1-4 specimens of Cibidoides wuellerstorfi $>250 \mu \mathrm{m}$ in size were analysed. Data were calibrated against the NBS-19 standard and with an internal laboratory standard of Solnhofen Limestone (refer to Sturm, 2003).

Procedures to analyse and count calcareous nannoplankton are outlined in Hiramatsu and De Deckker (1997a). Similarly, the procedures for the analysis of organic compounds from the same intervals as those selected for foraminifera analysis from the core are outlined in Calvo et al. (2004) and Pelejero, Calvo, Barrows, Logan, \& De Deckker (2009).

For the radiolarian studies the core was sampled from its top to $440 \mathrm{~cm}$. The carbonates were digested with $10 \%$ hydrochloric acid and, if any disaggregated clays remained, the samples were treated with $3 \%$ hydrogen peroxide and approximately 20 seconds of gentle ultrasound. The samples were then washed through a $63 \mu \mathrm{m}$ sieve, dried, and mounted in Norland $61^{\circledR}$. The radiolarians on the slides were examined at a magnification of 100 and counted by species.

Sea-surface temperature was estimated in two ways. The first one relies on the alkenone thermometry techniques and results on GC3 core are reported in Pelejero et al. (2009). Secondly, SST was calculated using the Modern Analog Technique (MAT) on planktonic foraminifera assemblages in conjunction with the AUSMAT-F4 coretop database (Barrows \& Juggins, 2005).

Small samples for grain size analysis were taken from the core at the same intervals as for the foraminifera and placed in $100 \% \mathrm{HCl}$ so as to dissolve the carbonate fraction and were left to settle for one day. After that, the residues were washed over a $60 \mu \mathrm{m}$ nylon sieve and 100 quartz grains were selected at random and their long axis was measured under a standard binocular microscope with a graticule. These analyses were performed by $\mathrm{Dr} \mathrm{L}$. Sbaffi. The mean value for 100 grains for each sample was calculated as well as the standard deviation.

The entire core was scanned with an Avaatech XRF core scanner at 1-cm resolution at the Royal Netherlands Institute for Sea Research (NIOZ), following established methods (Stuut, Juggins, Birks, \& van der Voet, 2014). Detailed bulk-chemical composition records acquired by XRF core scanning allow accurate determination of stratigraphical changes as well as assessment of the contribution of the various components in lithogenic and marine sediments. The core was measured at both $10 \mathrm{kV}$ and $30 \mathrm{kV}$ for 51 elements (Al, Si, P, S, Cl, K, Ca, Sc, Ti, V, Cr, Mn, Fe, Co, Ni, Cu, Zn, Ga, Ge, As, $\mathrm{Se}, \mathrm{Br}, \mathrm{Rb}, \mathrm{Sr}, \mathrm{Y}, \mathrm{Zr}, \mathrm{Nb}, \mathrm{Mo}, \mathrm{Tc}, \mathrm{Ru}, \mathrm{Rh}, \mathrm{Pd}, \mathrm{Ag}, \mathrm{Cd}$, In, Sn, Sb, Te, I, Cs, Ba, Hf, Ta, W, Re, Os, Ir, $\mathrm{Pt}, \mathrm{Au}, \mathrm{Hg}, \mathrm{Tl}, \mathrm{Pb}$ ). Log-ratios of two elements measured by XRF core scanning can be interpreted as the relative concentrations of two elements and minimises the effects of down-core changes in sample geometry and physical properties (Weltje \& Tjallingii, 2008). It is now well established that the elements $\mathrm{Ca}, \mathrm{Fe}$, and $\mathrm{Ti}$ (of interest here) can be measured reliably with the XRF-scanning method (Tjallingii, Röhl, Kölling, \& Bickert, 2007).

All the data used in this paper are available at www.pangaea.de . 


\section{Results}

\section{Chronology of the core}

The age model for the core was constructed by correlation with the benthic isotopic record and the chronostratigraphy of Liesicki and Raymo (2005). Thirty-seven tie points were matched between the two records and then fitted using a smoothing spline with the degree of smoothing determined using cross validation. The resulting root-mean-square error (RMSE) is $\pm 2.8 \mathrm{ka}$. This uncertainty is reasonable considering the average sedimentation rate for the core is $1 \mathrm{~cm} / \mathrm{ka}$ and samples were collected on average every $5 \mathrm{~cm}$. The sedimentation rate in the core is low, with $4.7 \mathrm{~m}$ representing $460 \mathrm{ka}$ of deposition with no apparent hiatus. The rate between tie points varies from $2 \mathrm{~cm} / \mathrm{ka}$ to 0.6 $\mathrm{cm} / \mathrm{ka}$ (see De Deckker et al., 2019, figure 3), and in general, sedimentation is slightly higher during interglacial periods. The new age model is slightly different from the one used by Hiramatsu and De Deckker (1997a) that employed tie points linked to the chronostratigraphy of Martinson et al. (1987) and a linear interpolation program (Analyseries; Paillard, Labeyrie, \& Yiou, 1996). The oxygen isotope data for both planktic and benthic foraminifera is presented in Figure 4 (A, B).

\section{Sedimentology}

The coarse fraction $(>150 \mu \mathrm{m})$ consists almost entirely of planktonic foraminifera with some benthic foraminifera, ostracods, a very few radiolarians and some quartz grains of terrigenous origin. The samples invariably contained sponge remains and the inorganic content consists of angular to very angular quartz grains. To assess dissolution, the preservation of the coccoliths of Calcidiscus leptoporus was examined by Hiramatsu and De Deckker (1997a). These authors found highest values during the interglacials as well as slightly lower values towards the end of each glacial phase suggesting a change of alkalinity in the ocean during those episodes.

\section{Planktic foraminifera}

The foraminifera identified in GC3 have been grouped into different assemblages that relate to biogeographical provinces recognised by Bé and Hutson (1977) for taxa found in the Indian Ocean. The various foraminifera assemblages are plotted in Figure 3.

\section{Antarctic and subantarctic Subantarctic faunas}

Cold-water forms (Subantarctic and Antarctic; referred to 'polar-subpolar' by Bé \& Hutson, 1977) are the most abundant group in the core, comprising between 25 and $70 \%$ of the total fauna. The most abundant species in this group, Globigerina bulloides, exceeds $20 \%$ of the total fauna throughout the core except during much of MIS 9 (Figure 5). Abundances this high are not currently present in the Tasman Sea (Thiede, Nees, Schulz, \& De Deckker, 1997) and are found only in the Southern Ocean (e.g. Kustanowich, 1963. Neogloboquadrina pachyderma (left-coiling = sinistral \& abbreviated here to 'sin.') in high numbers during glacial periods with its largest percentage in MIS 9 (Figures 3 and 4D). Globigerina quinqueloba is also more common during glacial periods (Figure 3 ).

\section{Transitional fauna}

The transitional fauna varies from 25 to $60 \%$. The abundance maxima occur during warm phases whereas the minima correspond with glacials. Neogloboquadrina pachyderma (right-coiling $=$ dextral and abbreviated here to 'dex.') with Globorotalia inflata are the most abundant forms together with Globorotalia truncatulinoides (Figure 4B). 


\section{Subtropical and tropical faunas}

The subtropical and tropical faunas comprise a minor component of the planktonic foraminifera, with values always below $8 \%$. The ubiquitous species Globigerinita glutinata (found in a broad range of temperatures in the Indian Ocean [14.7-29.7 ${ }^{\circ} \mathrm{C}$; Bé \& Hutson, 1977]) is the most significant species present and varies between $2-5 \%$, with abundance maxima during deglaciations and the peaks of interglacial periods (Figure 4C). A variety of warm water species also occur in low numbers: these include O. universa, G. falconensis, G. ruber, and G. hirsuta, which increase in abundance during the interglacial periods (Figure 3, uncoloured group).

Total fauna curve

The dominant taxa are presented together in Figure 3. Note that G. bulloides and N. pachyderma dex. are the most common species throughout the core and this assemblage relates to the nature of water masses found in the southwestern Tasman Sea.

Coiling ratio of Neogloboquadrina pachyderma

The coiling ratio (\% N. pachyderma sin.) varies from a few percent to close to $30 \%$ (Figure 4D). The highest values always coincide with glacial periods.

\section{$\delta^{13} \mathrm{C}$ of benthic foraminifera}

The carbon isotopic composition of benthic foraminifera can provide information on changes in productivity at or near the sea surface in the oceans, and of changes in deep-water masses caused by shifting bottom currents or density-driven changes. For example, Sikes, Elmore, Allen and Cook (2016) show that a better ventilated intermediate water can be deduced by $\delta^{13} \mathrm{C}$ enrichment and, in turn, this coincides with an upward restratification of the upper water mass when surface winds (such as the westerlies) are weakened. Figure 2D shows a stark contrast between the early glacials (MIS 12, 10, 8 and 6 ) and the early interglacials (MIS 11, 9 and 7 ) with glacial values much more negative. Interestingly, the last interglacial-glacial period (MIS 5 to 1 ) displays a different $\delta^{13} \mathrm{C}$ signal from previous stages recorded in this core because it is more subdued between the cold and warm phases.

\section{Benthic ostracods}

The ostracod species are all deep-water benthic in habit and belong to the genera Poseidonamicus, Krithe, Cytheropteron and Henryhowella. No shallow-water or freshwater forms were found, so no downslope transport occurred, suggesting that the core is free of turbidite sedimentation. The preservation of the ostracod valves varies from translucent (in rare occurrences) to white and chalky (common), commonly with delamination of the layered ultrastructure indicating peripheral corrosion. Using the preservation categories of ostracod valves introduced by Swanson and van der Lingen (1994), all samples fall within the average preservation index of 3 to 4 , indicating that the specimens have been substantially affected by post-mortem dissolution.

Since ostracods are highly susceptible to dissolution and valve degradation increases rapidly below 1500 m (Ayress, Neil, Passlow, \& Swanson, 1997), the abundance of ostracod valves also diminishes rapidly with depth beyond the continental shelf; this phenomenon is a function of decreasing biomass (of standing population of ostracods) and/or increasing dissolution with thanatocoenosis (Passlow, 1997).

Ostracod abundance downcore GC3, expressed as specimens per gram, varies strongly between interglacial and glacial periods (Supplementary papers, Figure S5). In view of the overall poor 
preservation of the valves, this variation is most likely to be a reflection of changes in the degree of corrosion rather than reflecting biological variability of the living ostracod population. Highest abundances are found in MIS 5 suggesting that only moderately corrosive bottom waters prevailed and that conditions on the sea floor were more favourable for the growth of ostracods. Very low abundances are found in MIS 2, 4 and the coolest phase of MIS 6, suggesting that the bottom water may have been highly corrosive during those glacials. Poor ostracod preservation is likely to be accentuated by the low sedimentation rates that increase the length of time valves are exposed to corrosive bottom waters. We obtained insufficient specimens to allow discussion on the possible change of taxa that are linked to different water masses. Nevertheless, we observed a higher abundance of Poseidonamicus major during MIS 3, 5a, and during the MIS 6 interstadial, but low numbers during MIS 7.

\section{Calcareous nannoplankton}

Today's ubiquitous Emiliania huxleyi, which is found in all oceans, is a complex species that characteristically has many different morphotypes some of which are correlated with different levels of alkalinity in the oceans, and, thus linked to sea surface temperatures (see Hiramatsu \& De Deckker, 1996 for samples taken in the Tasman Sea, which extend from the Subtropical Convergence $\left[46^{\circ} S\right.$ at the time of the cruise north to $43^{\circ} 30^{\prime} S$ ]). E. huxleyi abundance reached its zenith during the last glacial/interglacial cycle, with much lower percentages in the previous cycle and even lower values for the previous two cycles. Abundances varied over the Tasman Sea as shown by the comparison of three cores by Hiramatsu and De Deckker (1997a). This species is particularly abundant during the Holocene (Figure 5). It is difficult to evaluate the changes in percentages of the small Gephyrocapsa species and small placoliths together (see Hiramatsu \& De Deckker, 1997a) because of the predominance of $E$. huxleyi. Nevertheless, it is clear that the first two taxa are brought as far south in the Tasman Sea and reached the core site. Generally, the low percentages of Calcidiscus leptoporus, a species which normally inhabits high latitudes (Hiramatsu \& De Deckker, 1997b), confirm the limited importance of cold waters, except at the MIS 12/11 transition (Figures 4E and 5), thus suggesting a northerly shift of the STF for MIS 12-8. Florisphaera profunda, which generally lives in the lower photic zone (Okada \& Honjo, 1973), can be used as an indicator of surface wind strengthening and causing a shift of the position of the nutricline (Molfino \& McIntyre, 1990). Strong winds disturb the stratification of the water column and cause a shallowing of the thermocline and a compressed nutricline with resultant low $F$. profunda numbers (see Figure 4F).

\section{Radiolarians and diatoms}

The most notable feature of the counts is the change in radiolarian abundances between the samples. Samples for the two periods 24 to $4.6 \mathrm{ka}$ and 426 to 397 ka contain large numbers of radiolarian tests ( 1000 s per gram of sample). At about 405 ka the numbers drop sharply and between then and 170 ka essentially no tests are present. From 126 ka until 28 ka, there are small quantities consisting solely of Stylatractus neptunus (Haeckel) 1887, S. pluto (Haeckel) 1887, and Sphaerozoum punctatum Müller 1858. Thereafter, the quantities and the numbers of different species increase, slowly at first, then suddenly at about 11 ka to levels similar the 426-397 ka period.

The few tests observed between 120 and 25 ka are poorly preserved; preservation improves markedly after $25 \mathrm{ka}$. The abundances of S. neptunus, S. pluto, and Sphaerozoum punctatum observed in the 
surface sample were compared with the environmental variables but no significant correlations were found. It may, therefore, be deduced that the lack of radiolarian tests between 397 and $11 \mathrm{ka}$ is most probably due to poor preservation conditions and that the presence of S. neptunus, S. pluto, and Sphaerozoum punctatum alone between 126 and $28 \mathrm{ka}$ is a result of those species' greater resistance to dissolution. The poor preservation is compatible with the low sedimentation rate that allows siliceous tests to be dissolved in the waters undersaturated in silica at the sea floor before the tests are buried (Riedel, 1959; Riedel \& Funnell, 1964).

Cortese and Prebble (2015) have developed a modern reference dataset of the abundance of radiolarians covering an area of the south Pacific and Southern Ocean bounded by $10^{\circ} \mathrm{S}$ to $65^{\circ} \mathrm{S}$ in latitude, and $145^{\circ} \mathrm{E}$ to $170^{\circ} \mathrm{W}$ in longitude. To these counts were added the abundance counts for the GC3 surface sample, a transfer function for SSTs developed using weighted-averaging partial-least squares (ter Braak \& Juggins, 1993; ter Braak, Juggins, Birks, \& van der Voet, 1993), and the GC3 sea-surface temperature estimates (SST) reconstructed for the period 11 to 5 ka estimated (Supplementary papers, Figure S6). The SSTs for 9 to 5 ka (i.e. covering the Holocene Optimum) is 4 to $5{ }^{\circ} \mathrm{C}$ above the present day SST of $13.2^{\circ} \mathrm{C}$ (Locarnini et al., 2013); at $11 \mathrm{ka}$ it is $14 .{ }^{\circ} \mathrm{C}, 1^{\circ} \mathrm{C}$ above the present day value. It was not possible to estimate the SSTs earlier than that except for the period 408 to 393 ka due to the lack of radiolarians.

We note also that diatoms were not recovered from the core, despite the search for them by the late J.-J. Pichon. Interestingly, Calvo et al. (2004) identified $n$-alkanes in core GC3 (although the $n$-alkanes produced by diatoms cannot be distinguished from those produced by some Haptophyta algae).

\section{Fossil pollen and spores}

The majority of commonly occurring pollen and spores recorded in the GC3 core (see De Deckker et al., 2019, figure $5 \mathrm{a}-\mathrm{c}$ ) are types that are produced in very large numbers and widely dispersed by wind (wind-pollinated taxa). A summary diagram of the different vegetation biogeographical groups is presented (Figure 6).

\section{Grain size analysis of quartz grains}

First of all, we observe that quartz grains are found in all the samples, indicating continuous eolian transport over the core site. It is unlikely that terrigenous grains would have been transported at sea by dense river plumes because the east coast of Tasmania lacks major rivers and the core site is located $\sim 300 \mathrm{~km}$ from the nearest coastline. In addition, the core is located on a raised part of the sea floor. Of note is that we only measured grains that were $>60 \mu \mathrm{m}$. The original approach was to determine whether there was Ice Rafted Debris [IRD] in the core sediments, on the assumption that icebergs might have travelled as far as the East Tasman Plateau. No IRD (which generally consists of grains of different lithologies) was found; only quartz grains were recognised. XRF scanning of the entire core showed an abundance of silica (plotted here as Si/Al) throughout the core (Figure 7C), confirming frequent deposition of terrigenous material at sea. The measured mean size of 100 quartz grains indicates that, on average, the largest grains are found during the glacial periods, except during the MIS 2 when the mean diameter $(92 \mu \mathrm{m})$ is lower than in any other glacial episode, and even lower than during the entire MIS 5 (103-107 $\mu \mathrm{m}$; Figure 7C). The largest mean diameter for the quartz grains occurred during MIS $12(123 \mu \mathrm{m})$, but this is represented by only one sample (Figure 8B). 


\section{XRF core scanning analysis}

A variety of studies have tried to derive proxies for deposition of eolian material at sea from XRF scans of marine sediment cores and thus far it has been determined that the relative ratio of terrigenous to marine constituents can be best deduced from the elements such as titanium and calcium. The conservative element $\mathrm{Ti}$ is restricted to lithogenic sediments and inert to diagenetic process (Bloemsma et al., 2012; Calvert \& Pedersen, 2007; Tjallingii et al., 2007). In other instances, different elements have been investigated in ocean cores from close to continents, depending on the composition of the regional regolith. For example, for a core located offshore northwestern Australia, Stuut et al. (2014) used Fe as an indicator of river discharge to the ocean and De Deckker (2014) used $\mathrm{Y}$ for a core located offshore Kangaroo Island to indicate eolian material. The most commonly used ratio in deep-sea cores is $\mathrm{Ti}$ to $\mathrm{Ca}$ because the former element is a clear indicator of terrigenous supply via airborne dust deposited at the core site, whereas $\mathrm{Ca}$ is mostly representative of biogenic carbonate (Stuut et al., 2014).

The log ratios of several elements were used and compared with the $\delta^{18} \mathrm{O}$ curve for planktonic foraminifera (Figure 7). In Figure 7B, it is obvious that log ratio Ti/Ca is always greater during interglacials than glacials, although values during MIS 7 appear lower than for the other warm phases. The same overall pattern is seen in log ratio $\mathrm{Zr} / \mathrm{Rb}$, although during MIS 4 and the following period some low values are found. This is surprising because $\mathrm{Rb}$ is an element considered to represent substantial weathering on land. $\mathrm{Zr}$, on the other hand, is known to abound in eolian sediments in association with quartz, zircons being harder than quartz and not prone to weathering. However, it is noteworthy that the log ratios $\mathrm{Zr} / \mathrm{Rb}$ values are all $<1$, thus suggesting most of the sediments originating from arid regions, most likely mainland Australia, although parts of the midlands of eastern Tasmania are semi-arid today and even have saline to hypersaline lakes (De Deckker \& Williams, 1982). An additional log ratio, $\mathrm{Zr} / \mathrm{Si}$ (Figure $7 \mathrm{E}$ ), has negative values ranging from -0.95 to -0.45 , with once more the highest values occur during interglacial periods. The lowest values are registered during MIS 8 and 10, the highest in the earliest parts of MIS 6 and MIS 12. Comparison of the log ratios of $\mathrm{Zr} / \mathrm{Rb}$ and $\mathrm{Zr} / \mathrm{Si}$ in Figure $7(\mathrm{D}, \mathrm{E})$ demonstrates once again the dominance of $\mathrm{Zr}$, the element indicator of a supply from arid regions, over the two elements that derive from weathering conditions on land. The log ratio of $\mathrm{Si} / \mathrm{Al}$ indicates the greater supply of terrigenous material during interglacials, particularly MIS 9 and 5. The highest values of log ratio of Si/Al occur during MIS 4 and at $48.3 \mathrm{ka} \mathrm{BP.}$

\section{Sea-surface temperature and climate estimates}

Alkenone paleothermometry

Mean annual sea-surface temperatures using alkenone paleothermometry based on $\mathrm{UK}_{37}$ data were determined by Pelejero et al. (2009) and show an amplitude range between 4.3 and $6.9^{\circ} \mathrm{C}$, except for termination IV (the transition between MIS 10 and 9) that shows a dramatic increase of over $8{ }^{\circ} \mathrm{C}$ (Figure 8D). Note that alkenone paleothermometry generates a standard error of the order of $\pm 1.5^{\circ} \mathrm{C}$ (see Pelejero et al., 2009, for more information). Additionally, SST becomes progressively warmer during glacials with the coolest SST recorded during MIS 10 and the warmest during MIS 4 and 2. Of note also is that MIS 11 is the coolest of the interglacial periods at that site, and equally MIS 12 is almost as warm as MIS 2. 


\section{Modern analogue technique}

The mean annual SST presented in Figure 9B and the alkenone SST in Figure 9D show a clear temperature difference between the two techniques. The MAT square chord distances are mostly $<0.9$ (Figure 9F), indicating good analogues exist for the fossil faunas. On average there is a temperature difference of between $2.5^{\circ}$ and $5.5^{\circ} \mathrm{C}$. One exception is that the two are almost the same during MIS 10 whereas in MIS 12 the differences are at a maximum. The difference between the two techniques is that the foraminiferal SSTs rely on the total foraminiferal assemblage and some species definitely do not live at the sea surface, whereas the coccoliths that secrete alkenones all live in the photic zone. As already discussed for the alkenone SSTs, each glacial after MIS 10 registers a higher temperature than the previous one. In contrast, MIS 12 is $\sim 5^{\circ} \mathrm{C}$ warmer than MIS 10 .

We can assume that, when SSTs are similar between the two proxies, the thermocline must have been shallower, implying that winds above the core site were stronger and engendered a good mixing of the upper layers of the water column. This is particularly the case for MIS 6 and MIS 12, 8 and 2 (Figure 9B-D).

\section{Discussion}

The reconstructed parameters are compared and then the sequence of events reconstructed for the last $460 \mathrm{ka}$ at the core site, including the nature and timing of terrestrial changes east of Tasmania, are presented. Finally, we assess the regional changes such as atmospheric and oceanic boundaries, with overall vegetation trends (mostly discussed in the companion paper [De Deckker et al., 2019] over four glacial/interglacial cycles.

\section{Comparison between selected climate proxies}

A comparison between mean quartz grain diameters (as a proxy for wind strength; see Stanley \& De Deckker, 2002) and SST reconstructed from alkenones is provided in Figure 8 (B-D). Hesse and McTainsh (1999) considered that during glacial periods winds would have been stronger due to larger hemispheric temperature gradients. Commonly, strong winds can cause the thermocline depth to become shallower due to intense mixing of the upper layers of the ocean (Middleton \& Bye, 2007). Nevertheless, it appears that for several glacial periods (MIS 12, 10 and 2) mean grain diameters are smaller than the adjacent interglacial stages, MIS 1 being the exception. Indeed, for the early part of the Holocene, the mean diameters of the grains are the smallest recorded in the core. Thus, it appears that wind strength was quite different in the earliest part of the record (from 460 to $340 \mathrm{ka}$ ) compared to the rest of the record. Based on two cores, one west of New Zealand (E26.1, located at $40^{\circ} 17^{\prime} \mathrm{S}$ ) and the other in the middle of the Tasman Sea (E39.75, located at $36^{\circ} 29^{\prime} \mathrm{S}$ ), Hesse and McTainsh (1999) found no evidence of stronger winds during the LGM compared to the Holocene in the Tasman Sea. However, our proxy data suggests that during the Holocene wind strength was at its lowest compared to the rest of the core, but this is only based on two samples. A noteworthy observation is that in comparison with the plot of annual precipitation in Tasmania estimated from pollen (Figure 8C), mean quartz grain size does not coincide with low precipitation. Instead, for most periods of low precipitation, wind strength is diminished, at least for the last $340 \mathrm{ka}$. As mentioned earlier, Shulmeister et al. (2004), who assessed the latitudinal movements of the westerlies in the Australasian sector over the last glacial cycle, suggested that a westerly maximum occurred at the LGM, and a second one during the late Holocene. Our data, on the other hand, suggest that for the 
LGM, winds were not as strong as for the previous $400 \mathrm{ka}$, justifying the need for long records for generalising the behaviour of the westerlies over time.

\section{Comparison of different SST estimates}

There are technique specific differences between SST estimated from alkenone thermometry and the MAT as shown in Figure $9(B-D)$. A possible explanation is because alkenone temperatures usually relate to the spring flux of coccoliths as shown by Sikes, O'Leary, Noddler and Volkman (2005) and Sikes et al. (2009) in this region with additional complications due to environmental stresses such as nutrient (nitrate and phosphate) depletion (Sikes et al., 2005). Coccoliths may also be redistributed by surface currents as discussed earlier, although Hiramatsu and De Deckker (1997a) did not find any substantially old (reworked) specimens in the core. In contrast, the work by King and Howard (2001, 2003) on sediment traps located east of New Zealand indicates that the foraminiferal MAT is sufficiently accurate to estimate annual SST (as shown here in Figure 9B) despite the pronounced seasonality of foraminiferal production (King \& Howard, 2001, 2003). The estimated monthly maximum temperatures and the difference between these and the lower (Spring) alkenone temperatures (Figure 9C) are consistent with earlier conclusions.

Following from the early investigations of cores GC3 and E26-23, ODP Leg 189 undertook to core both the East Tasman Plateau (site 1172) and the South Tasman Rise (sites 1170 and 1171). Of interest are the investigations by Nürnberg et al. (2004) on core 1172 which examined terrigenous flux, SST and productivity for the last $500 \mathrm{ka}$. This was followed by an additional investigation on core 1172 combining SST and sea-surface salinity with implications for the position of the Subtropical Convergence. Our SST reconstructions based on the foraminifera MAT and alkenones (Figure 9B-D) overall match the findings of Nürnberg and Groeneveld (2006) on core ODP 1172A (Figure 1), which indicate that SSTs reconstructed from the $\mathrm{Mg} / \mathrm{Ca}$ technique were lower for MIS 7 than for MIS 5e, 9 and 11; values for MIS 7 and 11 are similar. In contrast, our SST values reconstructed from alkenones indicate that the coolest glacial period was MIS 10, a feature not found by Nürnberg and Groeneveld (2006). This is surprising since core site 1172A is located on the East Tasman Plateau, just $30 \mathrm{~km}$ from the GC3 core site. Hayward et al. (2012) used artificial neural networks (ANN-25), applied to foraminiferal assemblages and compared their proxy data to the foraminiferal MAT-35 technique, on two cores located in the eastern Tasman Sea near the South Island of New Zealand (MD06-2986 located at $43^{\circ} 26.91^{\prime} \mathrm{S}, 167^{\circ} 54^{\prime} \mathrm{E}$, and MD06-2989 located slightly north at $42^{\circ} 06.26^{\prime} \mathrm{S}, 168^{\circ} 52.72^{\prime} \mathrm{E}$ ). They showed that using both techniques, MIS12 SSTs were the coldest recorded for the last $500 \mathrm{ka}$, with very similar results, whereas using the MAT MIS 11 temperatures were very similar to those experienced at MIS $5 \mathrm{e}$. In contrast, the ANN-25 SSTs were much higher at MIS 11 of the order of 3 ${ }^{\circ} \mathrm{C}$.

\section{Comparison between SST and land temperatures and the behaviour of the East Australia Current near Tasmania}

Mean annual temperature, mean temperature of the warmest quarter and annual precipitation are presented in De Deckker et al. (2019, figure 7e-g), respectively. Comparison between alkenone SSTs and mean annual land temperatures estimated using the GC3 pollen spectra (De Deckker et al., 2019) shows several features (Figure 8C, D): (1) the range of estimated land temperatures is substantially smaller than for SST, being of the order of $\sim 2.5^{\circ} \mathrm{C}$; (2) mean annual land temperatures remain within 
the range of 8.5 to $12{ }^{\circ} \mathrm{C}$; (3) the range of land temperatures is moderate compared with the large SST excursions between glacials and interglacials; and (4) alkenone SST for the glacial periods differ by only $1{ }^{\circ} \mathrm{C}$ or less from the mean annual temperatures on land.

The fact that alkenone SST for the glacial periods differ by only $1{ }^{\circ} \mathrm{C}$ or less from the mean annual land temperature estimates (see Figure 9D, E) could imply that the EAC did not reach the core site during glacial periods. This hypothesis is reinforced by the comparison of mean annual temperatures from the pollen transfer function and the mean annual SST from foraminifera (Figure 9B), which indicate a similar pattern, except that the difference between ocean and land temperatures is much greater during MIS 9, implying an even stronger influence of the EAC during that period than during MIS 5e. The greater temperature difference between the two proxies during part of MIS 8 compared to glacial periods makes it likely that the EAC was present at that time. The warmest pollenreconstructed temperatures for the warmest quarter on land (Figure 10F) are consistently much higher $\left(\geq 4{ }^{\circ} \mathrm{C}\right.$ ) than the mean annual SST based on the foraminifera MAT, except for MIS 9 and MIS $5 \mathrm{e}$ and $5 \mathrm{~d}$. Care must be taken, however, as the reconstructions based on pollen rely on assumptions that the source function for the pollen in GC3 is that same as for the calibration sites on land. The range of oceanic temperature changes differs from the land temperatures because boundary conditions differ significantly between land and the ocean. Additional work is needed in this domain so as to better identify temperature changes over time. Nevertheless, we believe that this is the first ever attempt at comparing reconstructed land temperatures with two different SST methods.

It is noteworthy that the abundance variations through time of the dominant planktonic foraminifera $G$. bulloides and N. pachyderma dex. indicate the relative movements of the EAC and STF and displacement of surface water masses in the southern Tasman Sea.

A comparison between the percentage of alpine pollen as presented in the companion paper (De Deckker et al., 2019) and the mean annual land temperatures (see Figure 10B, E) shows that there is a clear pattern of low temperatures during MIS 10, 8 and 6, when alpine taxa proportions were highest. The LGM mean annual temperature was warmer than previous glacials when the percentage of alpine taxa was less than $2 \%$. It could also be suggested that due to the low alpine numbers, the transfer function applied to pollen return 'warmer' land temperatures, but this phenomenon is also matched by warmer SST during the LGM as shown by other proxies such as SSTs and the $\delta^{18} \mathrm{O}$ of planktic foraminifera. We suggest that conditions became drier during the LGM and as a result wet alpine shrubland became reduced in extent.

The palynological study of core TAN 0513-04 taken in the eastern Tasman Sea (42 $18^{\prime} \mathrm{S}, 169^{\circ} 53^{\prime} \mathrm{E}$ ) by Ryan et al. (2012), which spans the last $210 \mathrm{ka}$, displays a similar feature to that found in GC3. During MIS 6, there were higher percentages of montane-subalpine tree and shrub taxa than were recorded at MIS 2. During the latter period, Poaceaceae plus Chenopodiaceae were more abundant, perhaps indicating drier conditions (see discussion in De Deckker et al., 2019).

\section{Trace elemental ratios and supply of dust to the core site}

The trace elemental ratios ( $\mathrm{Ti} / \mathrm{Ca}, \mathrm{Zr} / \mathrm{Si}$, Si/Al, and $\mathrm{Zr} / \mathrm{Al}$; Figure $7 \mathrm{~B}-\mathrm{E}$ ) relate to dust that reached the core site principally from arid regions of mainland Australia, and possibly from the dry arid highlands of Tasmania near Tunbridge ( $42^{\circ} 07^{\prime} \mathrm{S}, 147^{\circ} 27^{\prime} \mathrm{E}$, at $\sim 200 \mathrm{~m}$ asl) (see De Deckker \& Williams, 1982), so it is surprising to see that the highest values consistently suggest that dust export to the core site was 
lower during glacial periods. This does not match the findings of Hesse (1994), who examined dust fluxes in the Tasman Sea between latitudes $30^{\circ} 33^{\prime} \mathrm{S}$ and $45^{\circ} 04.7^{\prime} \mathrm{S}$, found that the fluxes had increased during the glacial stages over the last four glacial/interglacial cycles. Our core is located just south of the dust plume recognised by Hesse (1994). Hess (1994) also found that the low dust fluxes from Australia occurred before $350 \mathrm{ka} \mathrm{BP}$ and were followed by an increase at MIS 10 .

Calvo et al. (2004) carried out a detailed analysis of molecular biomarkers on GC3 and found high levels of terrestrial $n$-alkanes that they interpreted as indicating a dust supply from the Australian mainland and/or Tasmania; the highest values were typically recorded during glacial periods. This finding and extrapolation for higher Fe concentrations contrasts with the XRF analyses presented here, which suggest that much of the sediment came from arid or semi-arid regions during interglacial periods. Calvo et al. (2004) postulated that Fe would have been consistently high during glacials. However, the log $(\mathrm{Fe} / \mathrm{K})$ values are only slightly higher during interglacials than during glacials (refer to data available at www.pangaea.de); thus not necessarily precluding the possibility of a high Fe input at the core site during glacial periods. It is possible also that the type of Fe was not bio-available within the water column. This idea is supported by the log $(\mathrm{Fe} / \mathrm{Ca}$ ) plot (refer to data available at www.pangaea.de) which does not provide a clear pattern, with values fluctuating between -2.9 for interglacials and -3.2 for glacials, with one exception: the early stage of MIS 10 has values as high as those found during MIS 5. Nevertheless, we need to be aware that Ca content may also be confounded by both dissolution and productivity in any core.

\section{Changes in the dissolved inorganic carbon of various water masses through time}

The $\delta^{13} \mathrm{C}$ of foraminifera reflects the $\delta^{13} \mathrm{C}$ of the dissolved inorganic carbon (DIC) of the water in which foraminifera form their tests (Ravelo \& Hillaire-Marcel, 2007), so it is possible to estimate changes in the DIC of the waters over core site GC3 on the East Tasman Plateau (today being the upper part of the 'Deep Water' water mass; see Supplementary papers, Figure S2) as well as the near sea surface where G. bulloides usually live (Bé \& Tolderlund, 1971). Figure 2 (C, D) shows that early in the record, the difference between the planktic and benthic foraminifera records $\left(\Delta \delta^{13} \mathrm{C}\right.$ is obtained by subtracting the $\delta^{13} \mathrm{C}$ of $\mathrm{G}$. bulloides from that of $C$. wuellerstorfi), with the near-zero values for $G$. bulloides matched by lower values of $\mathrm{C}$. wuellerstorfi during MIS 10. Similarly, the $\Delta \delta^{13} \mathrm{C}$ for MIS 7 displays high values like those of MIS 11, but as a result of lower $\delta^{13} \mathrm{C}$ values for $G$. bulloides $(\sim-0.8)$ and higher values for $C$. wuellerstorfi ( 0.3). At present, we are unable to determine the changes in the DIC of the water masses and the causes for such changes, but it is clear that the Deep Water that covered the East Tasman Plateau had a different signature during MIS 10 and 9 in contrast to the rest of the record (MIS 7-1), which displays smaller amplitudes of change between glacial and interglacials.

\section{Atmospheric and oceanic conditions and fronts}

The terrigenous material deposited at the core site indicates that, despite the stronger winds during the glacials (as indicated by the large mean diameter of quartz grains), proportionately more terrigenous material was delivered during interglacial periods, and yet this has not affected the sedimentation rate (Figure 3 in De Deckker et al., 2019). In fact, considering the dust storms that transited southeastern Australia over the last two decades, especially during the extensive drought that affected a large part of Australia (viz. the 'Red Dawn' event in Sydney in 2009 [De Deckker, et al., 2014], and the previous major one that affected Canberra in 2003 [De Deckker et al., 2008; De 
Deckker, Norman, Goodwin, Wain, \& Gingele, 2010]), it is not unexpected to find airborne dust material in the interglacial sediments in core GC3. De Deckker et al. (2010) presented satellite images that show that dust plumes can travel from mainland Australia over Tasmania on their way to the Southern Ocean. This suggests that during interglacial periods, such as the present, dust was blown to the core site. Previously, Goede, McCulloch, McDermott and Hawkesworth (1998), who examined the chemistry of a speleothem from Frankcombe Cave in south-central Tasmania, postulated that strontium isotopic ratios $\left({ }^{87} \mathrm{Sr} /{ }^{86} \mathrm{Sr}>0.70860\right)$ indicated a supply of aeolian dust above the cave site during interstadials. No dust Sr 'fingerprint' was found by these authors for the LGM, implying a different wind direction, viz. directly from the ocean to the west during the LGM and from the Australian mainland during the warmer period. Although the wind strength appears to have been stronger during the glacial periods than interglacial (Figure 8B), this observation does not hold for all glacial periods. For example, as stated before, mean grain size is low during the latter part of MIS 12 (ca $435 \mathrm{ka} \mathrm{BP}$ ), in the middle of MIS 10, and much lower during MIS 2 than during MIS 4: a larger mean diameter is recorded for the latter part of MIS 7. Thus, it is more than likely that the major dust plume from mainland Australia documented by Hesse (1994) traversed the Tasman Sea at a lower latitude, therefore not passing over the core site. Marino et al. (2008) recognised that the major elemental composition of dust deposited at EPICA Dome $C$ in Antarctica shows differences between the LGM and the Holocene, with an Australian signature present in the ice core during the Holocene. This points to different wind regimes between the two climatic phases, when more dust was deposited at the GC3 site during interglacial periods. This contrasts with the findings of Stuut et al. (2014) for whom dust deposition in a deep-sea core located offshore North West Cape at the northwestern tip of Western Australia typically occurred during the glacial periods of the last $550 \mathrm{ka}$. The source of that dust is proximal because desert dunes fringe the coast even today. In contrast, the eolian dust reaching the GC3 core site would have mostly come from inland central Australia with, possibly, a minor contribution from a small and often dry Tasmanian region. During wet phases on the Australian mainland large lakes fill up and large rivers break their banks, depositing large quantities of fluvial sediment. The deposits then deflate during subsequent dry periods (see O'Loinsigh et al., 2015). In conclusion, we suggest that during warm intervals terrigenous dust deposition offshore Tasmania results from fluctuating wet/humid phases and short dry periods, whereas dust exported offshore NW Western Australia primarily results from dry/arid phases typical in that part of Australia during glacial periods.

A comparison of the 51 sites in Tasmania (De Deckker et al., 2019, figure 6) shows that three sites in particular located in central Tasmania (35, Eagle Tarn; 36, Beatties Tarn; and 37, Camerons Lagoon (for more information refer to De Deckker , 2019 and Cook \& van der Kaars, 2006) provide the closest affinity with the pollen spectra recovered from core GC3. Thus, two different wind 'plumes' must have travelled over the GC3 core site; one coming from the west that delivered most of the pollen all year long, and the other from the northwest that brought most of the terrigenous material from the Australian mainland. Today several dust plumes originating from the Australian mainland have been witnessed during and towards the end of long periods of drought (see De Deckker et al., 2010). 


\section{Oceanic conditions in the region over the last $\mathbf{4 6 0} \mathrm{ka}$}

The variability of the EAC played a defining role in SST recorded offshore eastern Tasmania. We find that the glacial periods became progressively warmer with time, implying that during those glacial periods the EAC must still have brought warm waters, perhaps via eddies as far south as $44^{\circ} \mathrm{S}$. As the $E A C$ is an offshoot of the South Equatorial Current, we could assume that this current became stronger with time. Bard and Rickaby (2009) showed a migration of the subtropical front in the southern end of the Indian Ocean over core MD96-2077 located at $\sim 33^{\circ} \mathrm{S}$, and a progressive increase of SST obtained from alkenones over the last $460 \mathrm{ka}$ for the glacial periods. Prior to that period, glacial temperatures were warmer than for MIS 12. Equally, in the eastern Tasman Sea, the SSTs reconstructed by Hayward et al. (2012) using two different techniques based on foraminifera assemblages indicate that the glacial periods extending further back in time (MIS 18: ca 761-712 ka) than in GC3 and became progressively warmer through time. However, on the other side of New Zealand, SST reconstructions carried out by Ding, Wu, and Li (2017) and Xu et al. (2018) do not show any clear evidence of such a warming trend. Oceanographic conditions today (and in the past) remained different, especially as the Subantarctic Front is 'locked' by the topography of the Campbell Plateau (Hayward et al., 2012, and references therein).

The presence of the Subantarctic/Antarctic foraminifera species in the core, indicate that the Subtropical Front was south of the core site during interglacials but shifted northward during glacials (cf. Barrows et al., 2007). However, the percentages of the small Gephyrocapsa species combined with small placoliths (having eliminated E. huxleyi from the total counts; for further details refer to Hiramatsu \& De Deckker, 1997a), which reflect the strength of the EAC, demonstrate that this current became more important over the core site during the last two interglacial cycles. The oddity is that those combined percentages are low during MIS 11 and 9 in contrast to MIS 10, which displays higher values (Figure 5). As pointed out earlier, MIS 10 is quite different to the adjacent glacial periods.

\section{Conclusions}

The use of many different proxies applied to the study of core Fr1/94-GC3 has proven very informative concerning the reconstruction of conditions that not only affected the southern portion of the Tasman Sea offshore Tasmania, but it also permitted reconstruction of vegetational changes in northeastern Tasmania. Finally, we were able and document how terrestrial changes related to oceanic changes. De Deckker et al. (2019) provides the detailed palynological record of core Fr1/94-GC3 and should be consulted in parallel with this paper.

Several key findings are listed below:

1. There is good concordance between the two different proxies used to reconstruct past SSTs, although alkenone-derived SSTs provide warmer values during the interglacials. However, the two proxies provide estimates which differ by $<1{ }^{\circ} \mathrm{C}$ during glacial periods, suggesting that the thermocline was shallower during glacial periods as a result of stronger westerlies (see Middleton \& Bye, 2007).

2. The alkenone-derived SSTs are much higher than those predicted from the pollen-derived temperatures on land, again except for the glacial periods, suggesting that the calcareous nannoplankton that produced the alkenones could have been brought to the core site by the EAC, principally in large eddies, during interglacials. 
3. The last four glacial/interglacial cycles differ markedly from one another with, in particular, MIS 11 being cooler than MIS 9 , by the order of $2{ }^{\circ} \mathrm{C}$. This contrasts with the findings of Droxler and Farrell (2000), who established that MIS 11 was much warmer in many parts of the global ocean.

4. The EAC was definitely over the core site during MIS 11 but was not as important as during subsequent interglacials. In addition, as the last two glacial periods became warmer compared to the previous one, we anticipate that the EAC must have extended further south along the Tasmanian coast during those two last glacials, at least through its extensive eddies.

5. The glacial intervals became progressively warmer (and possibly drier) over the last $450 \mathrm{ka}$, and at the same time alpine shrubland in Tasmania declined.

6. The lowest record of precipitation for Tasmania occurred during the Last Glacial Maximum, although too few samples were analysed to be very representative.

7. The deposition of dust at the core site indicates a source from deflation of lakes and other sites such as large river banks following wet events on the Australian mainland during interglacial periods. This is supported for at least the last glacial/interglacial cycle by the $\mathrm{Sr}$ isotopic composition from a speleothem from Frankcombe Cave in south-central Tasmania.

8. The ostracod assemblage of GC3 indicates undisturbed hemipelagic deposition at least for the upper $2205 \mathrm{~cm}$ of the core from which ostracods were extracted. Neither is there any indication of reworking lower in the core as indicated by the absence of exotic calcareous nanofossils.

9. It appears that a significant change in dissolved inorganic carbon (as indicated by the $\delta^{13} \mathrm{C}$ of both planktic and benthic foraminifera) occurred in the southern part of the Tasman Sea above the core site between the earlier part of the sequence 460-240 ka BP and the later part (260-5 ka BP): this remains unexplained and requires further investigation.

\section{Acknowledgments}

The core was obtained during cruise Fr1-94 with the RV Lady Franklin which was funded by the Australian National Facility through a grant awarded to De Deckker. The original scientific crew consisted of Michael Ayress, Timothy Barrows, Leanne Armand [née Dansie], Chikara Hiramatsu, the

late Jean Jacques Pichon, Stefan Nees, Tony Rathburn and Patrick De Deckker. We acknowledge the great help from the late Bob Edwards, cruise manager at the time, and the captain, Neil Cheshire.

De Deckker is very grateful to Judith Shelley for proof reading several drafts of the manuscript and for technical assistance over the years. Allison Barrie helped process the stable-isotope samples of planktic foraminifera at RSES under the supervision of Joe Cali. We are grateful for Rineke Gieles for expertly and patiently scanning the cores at NIOZ. John Rogers is grateful to G. Cortese and J.

Prebble for a copy of their radiolarian counts. We acknowledge the reviews of Stephen Gallagher and Dioni Cendon, which helped improve the readability of the manuscript. Thank you both.

The preliminary contents of this paper were presented at the Australian Earth Science Convention in Canberra in 2010 when the senior author delivered the Mawson Lecture following his award of the Mawson Medal awarded by the Australian Academy of Science. Other data presented at that conference were published in De Deckker et al. (2014). 


\section{Supplementary papers}

Figure S1. Satellite image of part of southeastern Australia and Tasmania showing the plankton bloom occurring east of that island thought to be caused by the ubiquitous Emiliania huxleyi.

Figure S2. CTD profiles down to $3000 \mathrm{~m}$ for site $150^{\circ} \mathrm{E}, 44^{\circ} 15^{\prime} \mathrm{S}$ adjacent to the GC3 core site and a bit deeper. (A): Mean annual temperature and salinity versus depth. (B): Plots of mean annual nitrate, phosphate and silicate versus depth.

Figure S3. CTD plots down to $500 \mathrm{~m}$ for site $150^{\circ} \mathrm{E}, 44^{\circ} 15^{\prime} \mathrm{S}$ adjacent to the GC3 core site for temperature, salinity, nitrate and silicate for the four seasons.

Figure S4. Satellite image of a large portion of the southern hemisphere showing the typical frontal systems that pass over the southern portion of Australia and the associated cloud systems.

Figure S5. Plot of the percentages of selected dominant ostracod species recovered in the upper 200 $\mathrm{cm}[=220 \mathrm{ka} \mathrm{BP}]$ of the GC3 core.

Figure S6. Plots of SST estimates for GC3 using radiolarians (black line and dots) for discrete intervals for which abundant radiolarian taxa were recovered. (A) for three horizons in the Holocene also compared against the instrumental record, and (B) for MIS 12 and its transition into MIS 10 for five samples.

\section{References}

Alley, N. F. (1998). Cainozoic stratigraphy, palaeoenvironments and geological evolution of the Lake Eyre Basin. Palaeogeography, Palaeoclimatology, Palaeoecology 144, 239-263.

Ayress, M., Neil, H., Passlow, V., \& Swanson, K., (1997). Benthonic ostracods and deep water masses: A qualitative comparison of Southwest Pacific, Southern and Atlantic Oceans. Palaeogeography Palaeoclimatology Palaeoecology, 131, 287-302.

Bard, E., \& Rickaby, R. E. M. (2009). Migration of the subtropical front as a modulator of glacial climate. Nature, 460, 380-384.

Barrows, T. T., \& Juggins, S. (2005). Sea-surface temperatures around the Australian margin and Indian Ocean during the Last Glacial Maximum. Quaternary Science Reviews, 24, 1017-1047.

Barrows, T. T., Juggins, S., De Deckker, P., Calvo, E., \& Pelejero, C. (2007). Long-term sea surface temperature and climate change in the Australian-New Zealand region. Paleoceanography, 22, PA22215.

Bé, A. W. H., \& Hutson, W. H. (1977). Ecology of planktonic foraminifera and biogeographic patterns of life and fossil assemblages in the Indian Ocean. Micropaleontology, 23, 369-414.

Bé, A. W. H., \& Tolderlund, D. S. (1971). Distribution and ecology of living planktonic foraminifera in surface waters of the Atlantic and Indian Oceans. In B. M. Funnel \& W. R. Riedel (Eds.) The Micropaleontology of the Oceans (pp. 105-149). Cambridge: Cambridge University Press.

Belkin, I. M., \& Gordon, A. L. (1996). Southern Ocean fronts from the Greenwich meridian to Tasmania. Journal of Geophysical Research, 101, 3675-3696.

Berger, W. H., Bickert, T. Wefer, G., \& Yasuda, M. K. (1995). Brunhes-Matuyama boundary: 790 k.y. date consistent with ODP Leg 130 oxygen isotope records based on fit to Milankovitch template. Geophysical Research Letters, 22, 1525-1528. 
Bloemsma, M. R., Zabel, M., Stuut, J. B. W., Tjallingii, R., Collins, J. A., \& Weltje, G. J. 2012. Modelling the joint variability of grain size and chemical composition in sediments. Sedimentary Geology 280, 135-148.

Bowler, J. M. (1986). Spatial variability and hydrologic evolution of Australian lake basins: Analogue for Pleistocene hydrologic change and evaporite formation. Palaeogeography Palaeoclimatology Palaeoecology, 54, 21-41.

Calvert, S. E., \& Pedersen, T. F. (2007). Elemental proxies for palaeoclimatic and palaeoceanographic variability in marine sediments: interpretation and application. Developments in Marine Geology 1 , 567-644.

Calvo, E., Pelejero, C., Logan, G. A., \& De Deckker, P. (2004). Dust-induced changes in phytoplankton composition in the Tasman Sea during the last four glacial cycles.

Paleoceanography, 19, PA2020 10.1029/2003PA000992.

Cook, E. J., \& van der Kaars, S. (2006). Development and testing of transfer functions for generating quantitative climatic estimates from Australian pollen data. Journal of Quaternary Science, 21, 723-733.

Cortese, G., \& Prebble, J. (2015). A radiolarian-based modern analogue dataset for palaeoenvironmental reconstructions in the southwest Pacific. Marine Micropaleontology, 118, 34-40.

De Deckker, P. (2014). Fingerprinting aeolian dust in marine sediment: examples from Australia. PAGES News, 22, 80-81.

De Deckker, P., \& Williams, W. D. (1982). Chemical and biological features of Tasmanian salt lakes. Australian Journal of Marine and Freshwater Research, 33, 1127-1132.

De Deckker, P., Abed, R. M. M., de Beer, D., Hinrichs, K.-U., O’Loingsigh, T., Schefuß, E., Stuut, J.-B. W., Tapper, N. J., \& van der Kaars, S. (2008). Geochemical and microbiological fingerprinting of airborne dust that fell in Canberra, Australia, in October 2002. Geochemistry Geophysics Geosystems, 9, Q12Q10, DOI:10.1029/2008GC002091.

De Deckker, P., Barrows, T. T., \& Rogers, J. (2014). Land-sea correlations in the Australian region: post-glacial onset of the monsoon in northwestern Western Australia. Quaternary Science Reviews, 105, 181-194.

De Deckker, P., Moros, M., Perner, K., \& Jansen, E. (2012). Influence of the tropics and southern westerlies on glacial interhemispheric asymmetry. Nature Geoscience, 5, 266-269.

De Deckker, P., Munday, C., Brocks, J., O'Loingsigh, T., Allison, G. E., Hope, J., Norman, M., Stuut, JB. W., Tapper, J. J., \& van der Kaars, S. (2014). Characterisation of the major dust storm that traversed over eastern Australia in September 2009; a multidisciplinary approach. Aeolian Research, 15, 133-149.

De Deckker, P., Norman, M., Goodwin, I. A., Wain, I. A., \& Gingele, F. X. (2010). Lead isotopic evidence for an Australian source of aeolian dust to Antarctica at times over the last 170,000 years. Palaeogeography Palaeoclimatology Palaeoecology, 285, 205-233.

De Deckker, P., van der Kaars, S., Macphail, M., \& Hope, G. (2019). Land-sea correlations in the Australian region: $460 \mathrm{k}$ years of changes recorded in a deep-sea core offshore Tasmania. Part 1: the pollen record. Australian Journal of Earth Sciences, 66 
Ding, X., Wu, Y.-Y., \& Li, W. (2017). A new 0.9 Ma oxygen isotope stratigraphy for a shallow water sedimentary transect across three IODP 317 sites in the Canterbury bight of Southwest Pacific Ocean. Palaeogeography Palaeoclimatology Palaeoecology, 465, 1-13.

Droxler, A. W., \& Farrell, J. W. (2000). Marine Isotope Stage 11 (MIS 11): new insights for a warm future. Global and Planetary Change, 24, 1-5.

EPICA Community Members (2004). Eight glacial cycles from an Antarctic ice core. Nature, 429, 623628.

Feary, D., Pratchett, M., Emslie, M. J., Fowler, A. M., Figueira, W. F., Luiz, O. J., Nalamura, Y., \& Booth, D. J. (2014). Latitudinal shifts in coral reef fishes: why some species do and others do not shift. Fish and Fisheries, 15, 593-615.

Gentilli, J. (1971). Dynamics of the Australian troposphere. Climates of Australia and New Zealand. World Survey of Climatology 13 (pp. 53-117). Amsterdam: Elsevier Publishers.

Goede, A., McCulloch, M., McDermott, F., \& Hawkesworth, C. (1998). Aeolian contribution to strontium and strontium isotope variations in a Tasmanian speleothem. Chemical Geology, 149, $37-50$.

Hays, J. D., Imbrie, J., \& Shackleton, N. J. (1976). Variations in the Earth's Orbit: pacemaker of the Ice Ages. Science, 194, 1121-1132.

Hayward, B. W. Sabaa, A. T., Kolodziej, A., Crundwell, M. P., Steph, S., Scott, G., Neil, H., Bostock, H. C., Carter, L., \& Grenfell, H. (2012). Planktic foraminifera-based sea-surface temperature record in the Tasman Sea and history of the Subtropical Front around New Zealand, over the last one million years. Marine Micropaleontology, 82/83, 13-27.

Hesse, P. P. (1994). The record of continental dust from Australia in Tasman Sea sediments. Quaternary Science Reviews, 13, 257-272.

Hesse, P. P., \& McTainsh, G. H. (1999). Last glacial maximum to early Holocene wind strength in the mid-latitudes of the Southern Hemisphere from aeolian dust in the Tasman Sea. Quaternary Research, 52, 343-349.

Hesse, P. P., Magee, J. W., \& van der Kaars, S. (2004). Late Quaternary climates of the Australian arid zone: a review. Quaternary International, 118, 87-102.

Hiramatsu, C., \& De Deckker, P. (1996). The distribution of calcareous nannoplankton near the subtropical convergence, south of Tasmania. Australian Journal of Marine and Freshwater Research, 47, 707-713.

Hiramatsu, C., \& De Deckker, P. (1997a). The Late Quaternary calcareous nannoplankton assemblages from three cores from the Tasman Sea. Palaeogeography Palaeoclimatology Palaeoecology, 131, 391-412.

Hiramatsu, C., \& De Deckker, P. (1997b). The calcareous nannoplankton assemblages of surface sediments in the Tasman and Coral Seas. Palaeogeography Palaeoclimatology Palaeoecology, 131, 257-285.

Hodgson, D. A., \& Sime, L.C. (2010). Southern westerlies and $\mathrm{CO}_{2}$. Nature Geoscience, 3, 666-667

Kawagata, S. (1999). Late Quaternary bathyal benthic foraminifera from three Tasman Sea cores, southwest Pacific Ocean. Scientific Reports of the Institute of Geoscience of the University of Tsukuba, 20, 1-46. 
Kawagata, S. (2001) Tasman Front shifts and associated paleoceanographic changes during the last 250,000 years: foraminiferal evidence from the Lord Howe Rise. Marine Micropaleontology, 41, 167-191.

Kawahata, H. (2002). Shifts in oceanic and atmospheric boundaries in the Tasman Sea (Southwest Pacific) during the Late Pleistocene: evidence from organic carbon and lithogenic fluxes.

Palaeogeography Palaeoclimatology Palaeoecology, 184, 225-249.

King, A. L., \& Howard, W. R. (2001). Seasonality of foraminiferal flux in sediment traps at Chatham Rise, SW Pacific: Implications for paleotemperature estimates. Deep Sea Research I 48, 1687 1708.

King, A. L., \& Howard, W. R. (2003). Planktonic foraminiferal flux seasonality in Subantarctic sediment traps: A test for paleoclimatic reconstructions. Paleoceanography 18, 1019, doi:10.1029/2002PA000839.

Kustanowich, S. (1963). Distribution of planktic foraminifera in surface sediments of the south-west Pacific Ocean. New Zealand Journal of Geology and Geophysics 6, 534-565.

Lisiecki, L. E., \& Raymo, M. E. (2005). A Pliocene-Pleistocene stack of 57 globally distributed benthic $\delta^{18} \mathrm{O}$ records. Paleoceanography, 20, PA1003, doi:10.1029/2004PA001071.

Locarnini, R., Mishonov, A. V., Antonov, J. I., Boyer, T. P., Garcia, H. E., ...\& Seidov, D. (2013). World Ocean Atlas 2013 Volume 1: Temperature. US Government Printing Office, Washington, D.C.

Luick, J. L., Käse, R., \& Tomczak, M. (1994). On the formation and spreading of the Bass Strait cascade. Continental Shelf Research 14, 385-399.

Magee, J. W., Miller, G. H., Spooner, N. A., \& Questiaux, D. (2004). Continuous 150 k.y. monsoon record from Lake Eyre, Australia: Insolation-forcing implications and unexpected Holocene failure. Geology, 32, 885-888.

Marino, F., Castellano, E., Ceccato, D., De Deckker, P., Delmonte, B., Ghermandi, G., Maggi, V., Petit, J. R., Revel-Rolland, M., \& Udisti, R. (2008). Defining the geochemical composition of the EPICA Dome C ice core dust during the last Glacial-Interglacial cycle, Geochemistry, Geophysics, Geosystems 9, Q10018, doi:10.1029/2008GC002023.

Martinez, J. I. (1994). Late Pleistocene palaeoceanography of the Tasman Sea: implications for the dynamics of the warm pool in the western Pacific. Palaeogeography Palaeoclimatology Palaeoecology, 112, 19-62.

Martinez, J. I. (1997). Decreasing influence of Subantarctic Mode Water north of the Tasman Front over the past 150 kyr. Palaeogeography Palaeoclimatology Palaeoecology, 131, 355-364.

Martinson, D. G., Pisias, N. G., Hays, J. D., Imbrie, J., Moore, T. C., \& Shackleton, N. J. (1987). Age dating and the orbital theory of ice ages: Development of a high-resolution 0 to 300,000-year chronostratigraphy. Quaternary Research, 27, 1-29.

Marx, S., Kamber, B. S, \& McGowan, H. A. (2005). Provenance of long-travelled dust determined with ultra-trace-element composition: a pilot study with samples from New Zealand glaciers. Earth Surface Processes and Landform, 30, 699-716.

Middleton, J., \& Bye, J. A. T. (2007). A review of the shelf-slope circulation along Australia's southern shelves: Cape Leeuwin to Portland. Physical Oceanography, 75, 1-41. 
Molfino, B., \& McIntyre, A. (1990). Precessional forcing of nutricline dynamics in the equatorial Atlantic. Science, 249, 766-769.

Nees, S. (1997). Late Quaternary paleoceanography of the Tasman Sea: the benthic foraminiferal view. Palaeogeography Palaeoclimatology Palaeoecology, 131, 365-389.

Nees, S., Armand, L., De Deckker, P., Labracherie, M., \& Passlow, V. (1997). A diatom and benthic foraminiferal record from the South Tasman Rise (Southeastern Indian Ocean): implications for paleoceanographic changes over the last 200,000 years. Marine Micropaleontology 38, 69-80.

Nees, S., Martinez, J. I., De Deckker, P., \& Ayress, M. (1994). A stable-isotope record for the Late Quaternary from the East Tasman Plateau. In G. J. van der Lingen, K. M. Swanson \& R. J. Muir (Eds.), The evolution of the Tasman Sea Basin. Proceedings of the Tasman Sea Conference November 1992, Christchurch, New Zealand (pp. 197-201). Rotterdam: Balkema.

Nürnberg, D., \& Groeneveld, J. (2006). Pleistocene variability of the Subtropical Convergence at East Tasman Plateau: Evidence from Planktonic foraminiferal Mg/Ca (ODP Site 1172A). Geochemistry Geophysics Geosystems, 7, doi:10.1029/2005GC000984

Nürnberg, D., Brughmans, N., Schönfeld, J., Ninnemann, U., \& Dullo, C. (2004). Paleo-export production, terrigenous flux and sea surface temperatures around Tasmania - Implications for glacial/interglacial changes in the subtropical convergence zone. In N. F. Exon, J. P. Kennett \& M. J. Malone (Eds.), The Cenozoic Southern Ocean: Tectonics, Sedimentation, and Climate Change Between Australia and Antarctica (pp. 291-318). Washington DC: AGU, Geophysical Monograph 151.

Okada, H. \& Honjo, S. (1973). The distribution of oceanic coccolithophorids in the Pacific. Deep-Sea Research 20, 355-374..

O'Loingsigh, T., McTainsch, G. H., Parsons, K., Strong, C. L., Shinkfield, P., \& Tapper, N. J., (2015). Using meteorological observer data to compare wind erosion during two great droughts in eastern Australia; the World War II Drought (1937-1946) and the Millennium Drought (2001-2010). Earth Surface Processes and Landforms, 40, 123-130.

Paillard, D., Labeyrie, L., \& Yiou, P. (1996). Macintosh Program performs time-series analysis. EOS, 77, 379. DOI: 10.1029/96EO00259.

Passlow, V. (1997). Quaternary ostracods as palaeoceanographic indicators: a case study off southern Australia. Palaeogeography Palaeoclimatology Palaeoecology, 131, 315-325.

Pelejero, C., Calvo, E., Barrows, T. T., Logan, G. A., \& De Deckker, P. (2009). South Tasman Sea alkenone palaeothermometry over the last four glacial/interglacial cycles. Marine Geology, 230, 73-86.

Ravelo, A. C., \& Hillaire-Marcel, C. (2007). The use of oxygen and carbon Isotopes of Foraminifera In paleoceanography. Developments in Marine Geology, 1, 735- 764.

Ridgway, K. R. (2007). Long-term trend and decadal variability of the southward penetration of the East Australian Current. Geophysical Research Letters, 34, L13613.

Ridgway, K. R., \& Hill, K. (2009). The East Australian Current. In E. S. Poloczanska, A. J. Hobday \& A. J. Richardson (Eds.), A Marine Climate Change Impacts and Adaptation Report Card for Australia 2009. NCCARF Publication. 
Riedel, W. R. (1959). Siliceous organic remains in pelagic sediments. In Silica in Sediments (pp. 8091). Society of Economic Paleontologists and Mineralogists, Special Publication

Riedel, W. R., \& Funnell, B. M. (1964). Tertiary sediment cores and microfossils from the Pacific Ocean floor. Quaternary Journal of the Geological Society of London 120, 305-368.

Rochford, D. J. (1957). The identification and nomenclature of the surface water masses in the Tasman Sea. Australian Journal of Marine and Freshwater Research, 8, 369-413.

Ryan, M. T., Dunbar, G. B., Vandergoes, M. J., Neil, H. L., Hannah, M. J., Newnham, R. M., Bostock, H., \& Alloway, B. V. (2012). Vegetation and climate in Southern Hemisphere mid-latitudes since 210 ka: new insights from marine and terrestrial pollen records from New Zealand. Quaternary Science Reviews, 48, 80-98.

Saito, T., Thompson, P. R., \& Berger, D. (1981). Systematic Index of Recent and Pleistocene Planktonic Foraminifera. Tokyo: University of Tokyo Press.

Shulmeister, J., Goodwin, I., Renwick, J., Harle, K., Armand, L., McGlone, M. S., Cook, E., Dodson, J., Hesse, P. P., Mayeswski, P., \& Curran, M. (2004). The Southern Hemisphere westerlies in the Australasian sector over the last glacial cycle: a synthesis. Quaternary International, 118, 25-53.

Sikes, E. L., Elmore, A. C., Allen, K. A., \& Cook, M. S. (2016). Glacial water mass structure and rapid $\delta^{18} \mathrm{O}$ and $\delta^{13} \mathrm{C}$ changes during the last glacial termination in the Southwest Pacific. Earth and Planetary Science Letters, 456, 87-97.

Sikes, E. L., Howard, W. R., Samson, C. R., Mahan, T. S., Robertson, L. G., \& Volkman, J. K. (2009). Southern Ocean seasonal temperature and Subtropical Front movement on the South Tasman Rise in the late Quaternary. Paleoceanography, 24, PA2201, doi:10.1029/2008PA001659.

Sikes, E. L., O'Leary, T., Noddler, S. D., \& Volkman, J. K. (2005). Alkenone temperature records and biomarker flux at the subtropical front on the Chatham Rise, SW Pacific Ocean. Deep-Sea Research I, 52, 721-748.

Singh, G., \& Geissler, E. A. (1985). Late Cainozoic History of Vegetation, Fire, Lake Levels and Climate, at Lake George, New South Wales, Australia. Philosophical Transactions of the Royal Society of London. Series B, Biological Sciences, 311, 379-447.

Stanley, S., \& De Deckker, P. (2002). A Holocene record of allochthonous mineral grains into an Australian alpine lake; implications for the history of climate change in southeast Australia. Journal of Paleolimnology, 27, 207-219.

Sturm, A. (2003). Changes in oceanic circulation and carbonate chemistry in the Australian sector of the Southern Ocean during the last 500,000 years. Kiel, Germany: Christian-Albrechts University [unpublished].

Sturman, A., \& Tapper, N. J. (1996). The weather and climate of Australia and New Zealand. South Melbourne Vic: Oxford University Press (1 ${ }^{\text {st }}$ edition).

Stuut, J.-B. W., Juggins, S., Birks, H., \& van der Voet, P. (2014). A 550 ka record of aeolian activity near North West Cape, Australia: inferences from grain-size distributions and bulk cheMIS try of SE Indian Ocean deep-sea sediments. Quaternary Science Reviews, 83, 83-94.

Swanson, K., \& van der Lingen, G. J. (1994). Podocopid ostracod dissolution - description of a new palaeoenvironmental tool, with examples from the eastern Tasman Sea. In G. J. van der Lingen, K. M. Swanson \& R. J. Muir (Eds.), The evolution of the Tasman Sea Basin. Proceedings of the 
Tasman Sea Conference November 1992, Christchurch, New Zealand (pp. 245-260). Rotterdam: Balkema.

ter Braak, C., \& Juggins, S. (1993). Weighted averaging partial least squares regression (WA-PLS): an improved method for reconstructing environmental variables from species assemblages. Hydrobiologia, 269/270, 485-502.

ter Braak, C., Juggins, S., Birks, H., \& van der Voet, H. (1993). Weighted averaging partial least squares regression (WA-PLS): definition and comparison with other methods for speciesenvironment calibration. In G. Patil \& C. Rao (Eds.) Multivariate Environmental Statistics (pp. 525-560). Amsterdam: Elsevier Science Publishers, North Holland series in Statistics and Probability.

Tjallingii, R., Röhl, U., Kölling, M., \& Bickert, T. (2007). Influence of the water content on X-ray fluorescence core- scanning measurements in soft marine sediments. Geochemistry Geophysics Geosystems, 8, Q02004, doi:10.1029/2006GC001393.

Thiede, J., Nees, S., Schulz, H., \& De Deckker, P. (1997). Oceanic surface conditions recorded on the sea floor of the Southwest Pacific Ocean through the distribution of foraminifers and biogenic silica. Palaeogeography Palaeoclimatology Palaeoecology, 131, 207-239.

Tomczak, M., \& Godfrey, J. S. (2003). Regional Oceanography: An Introduction. Oxford UK: Pergamon Press ( $2^{\text {nd }}$ edition).

Weltje, G. J., \& Tjallingii, R. (2008). Calibration of XRF core scanners for quantitative geochemical logging of sediment cores: theory and application. Earth and Planetary Science Letters, 274, 423 438.

Wu, Y., Ding, X., Hu, K. (2018). A 450-kyr planktonic foraminiferal assemblage record of IODP site U1352 and its implications for the migration of the subtropical front in the southwest Pacific. Marine Micropaleontology, 141, 31-41.

\section{Figure captions}

Figure 1. Bathymetric map of the western sector of the Tasman Sea showing part of eastern Australia and Tasmania with their reliefs. The principal surface currents are shown, in yellow for winter flows and red for summer ones. Note the presence of eddies associated with the East Australia Current: their locations continuously vary. Abbreviations: EAC, East Australia Current; TF, Tasman Front; TO, Tasman Overflow [shown in blue]; ZC, Zeehan Current; STC, Subtropical Convergence (also called Subtropical Front). Note the position of the latter varies between seasons and is linked to the Westerlies. The white arrows between the Australian mainland and the EAC is a northward moving coastal counter current. Compare these with the cold coastal counter current visible in Figure 3. The location of many of the cores discussed in the text is also shown. Core E26-23 is located near Fr1-94-GC3. The base map was produced by Brian Harrold using the GEBCO's gridded bathymetric data - GEBCO_2014 Grid (30 arc-second interval). http://www.gebco.net/data_and_products/gridded_bathymetry_data/

Figure 2. Plots of the $\delta^{18} \mathrm{O}$ of the planktic foraminifera $G$. bulloides $(\mathrm{A})$ and the benthic foraminifera $C$. wuellerstorfi $(\mathrm{B})$ against age for core GC3. The ages used in this diagram were obtained by using tie points based on the Lisiecki and Raymo (2005) chronology, then applying the benthic curve. In 
(C) and (D) are the plots of the $\delta^{13} \mathrm{C}$ of both foraminifera species. Note that the MIS chronologies are presented at the top of the figure and that the various stages appear as vertical dashed lines.

Figure 3. Plot of the dominant planktic foraminifera taxa recovered in core GC3 versus age. All the species other than the most common are plotted together as the uncoloured group on the right of the diagram. MIS chronologies are shown on the right.

Figure 4. Plot of the percentages of individual planktic foraminifera taxa recovered in core GC3 compared to (A) the $\delta^{18} \mathrm{O}$ of the planktic foraminifer $G$. bulloides versus age; (B) for $G$. truncatulinoides; (C) for G. glutinata; (D) for N. pachyderma sinistral. Percentages of selected nannoplankton taxa are presented in (E) for Leptoporus sp., and in (F) for $F$. profunda. MIS chronologies are shown at the top.

Figure 5. Plot of the key abundant calcareous nannoplankton taxa recovered in core GC3 versus age. All the species other than the most common are plotted together as the uncoloured group on the right of the diagram. MIS chronologies are shown on the right.

Figure 6. Generalised plot of the different pollen biogeographical groups recognised in core GC3 versus age. MIS chronologies are shown on the right.

Figure 7. Plot of the $\delta^{18} \mathrm{O}$ of the planktic foraminifera $G$. bulloides for core GC3 versus age (A), with blue shadings indicating glacials and red shadings interglacials, compared with various elemental ratios obtained through XTF scanning of the core: (B) $\log \mathrm{Ti} / \mathrm{Ca}$, (C) $\log \mathrm{Si} / \mathrm{Ca}$, (D) $\log \mathrm{Zr} / \mathrm{Al}$, and (E) $\log \mathrm{Zr} / \mathrm{Si}$. MIS chronologies are shown at the top.

Figure 8. Plot of the $\delta^{18} \mathrm{O}$ of the planktic foraminifera $G$. bulloides for core GC3 versus age (A), with blue shadings indicating glacials and red shadings interglacials, compared with the record of the mean diameter of 100 quartz grains in each sample (B), the reconstructed annual precipitation reconstructed from pollen assemblages $(C)$, and the reconstructed sea-surface temperatures based on alkenones (D). MIS chronologies are shown at the top.

Figure 9. Plot of the $\delta^{18} \mathrm{O}$ of the planktic foraminifera $G$. bulloides for core GC3 versus age (A), with blue shadings indicating glacials and red shadings interglacials, compared with in (B) reconstructed mean SST based on planktic foraminiferal faunal associations, in (C) reconstructed maximum SST as based on foraminiferal faunal associations, in (D) reconstructed SST based on alkenones produced by calcareous nannoplankton, in (E) reconstructed mean annual temperatures based on pollen, and in $(F)$ are the square chord distance calculations for the mean annual SST reconstructions obtained from foraminifera. See text for additional information. MIS chronologies are shown at the top.

Figure 10. Plots of the $\delta^{18} \mathrm{O}$ of the planktic foraminifera $G$. bulloides for core GC3 versus age (A), with blue shadings indicating glacials and red shadings interglacials. This is compared against the various plant groups: (B) alpine taxa, (C) rainforest taxa, and (D) herbs. In (E), mean annual temperature, $(F)$ mean temperature of the warmest quarter, and $(G)$ annual precipitation, all the last three were reconstructed from the pollen data (see text for details). The arrows at the bottom of the diagram indicates the general noticeable trends through time (from old to young): (A) a progressive decrease in $\delta^{18} \mathrm{O}$ values over the glacial periods, and $(\mathrm{B})$ a decrease in the percentage of alpine taxa. MIS chronologies are shown at the top. 


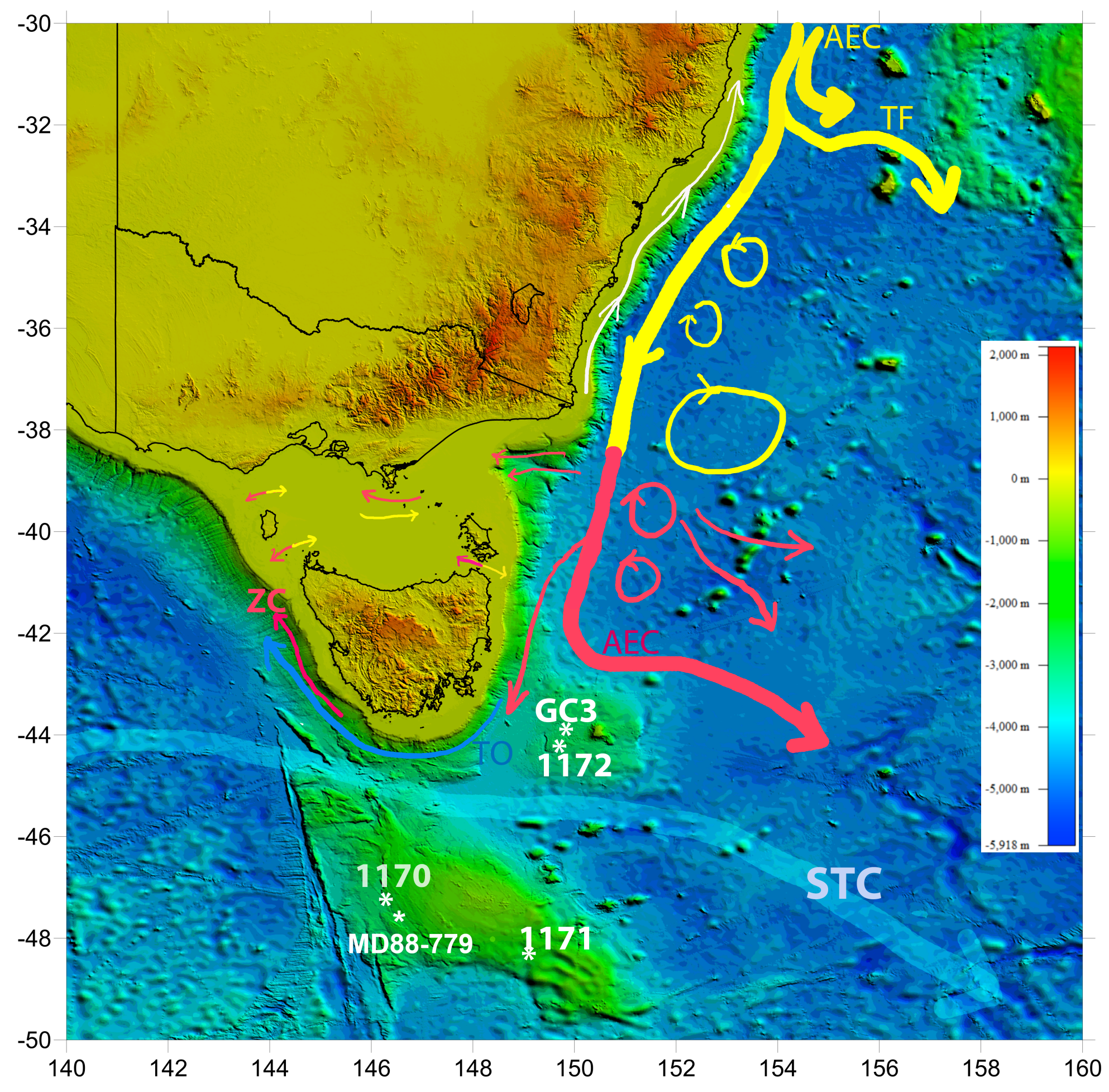




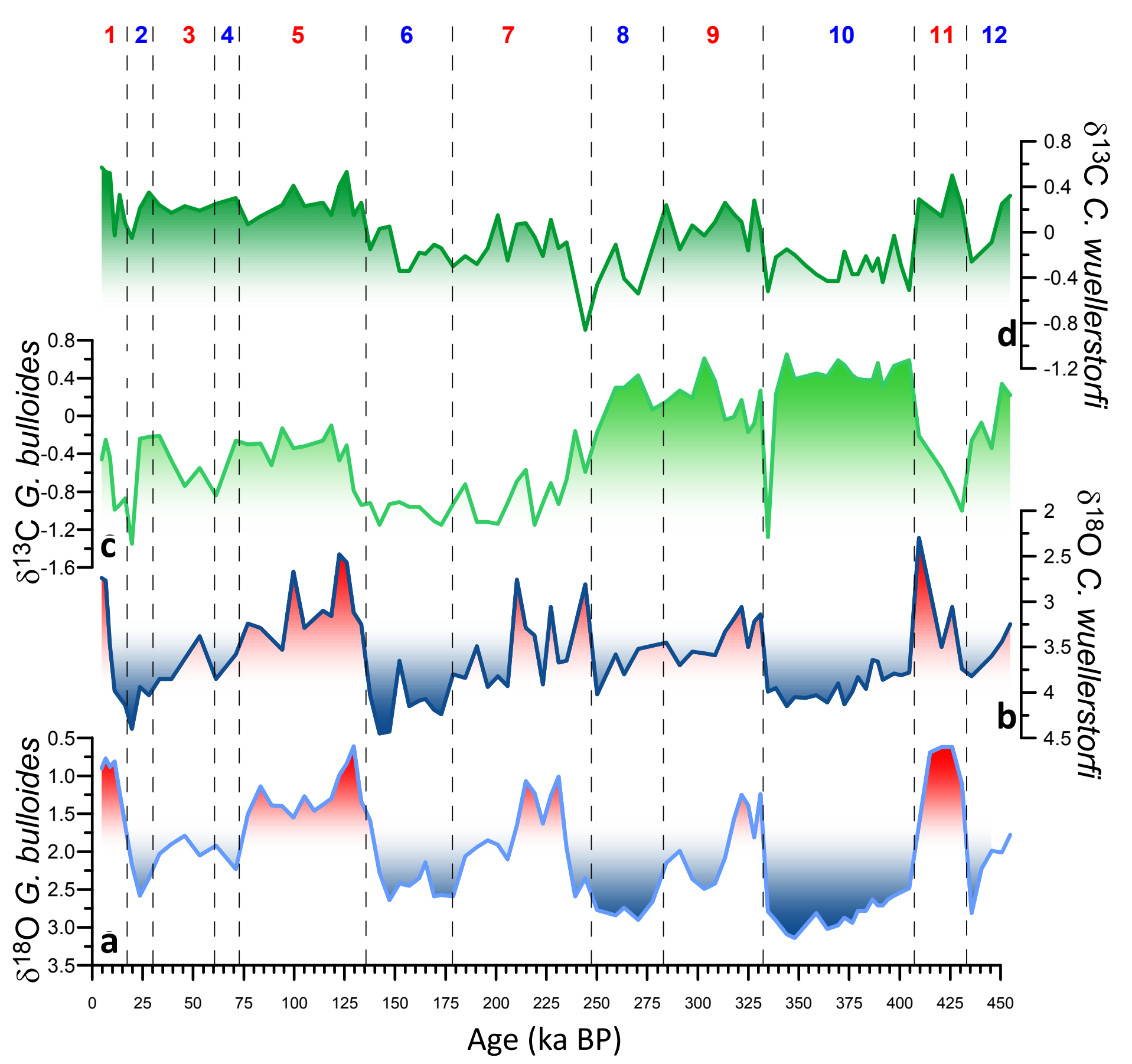




\section{\% Dominant foraminifera species}

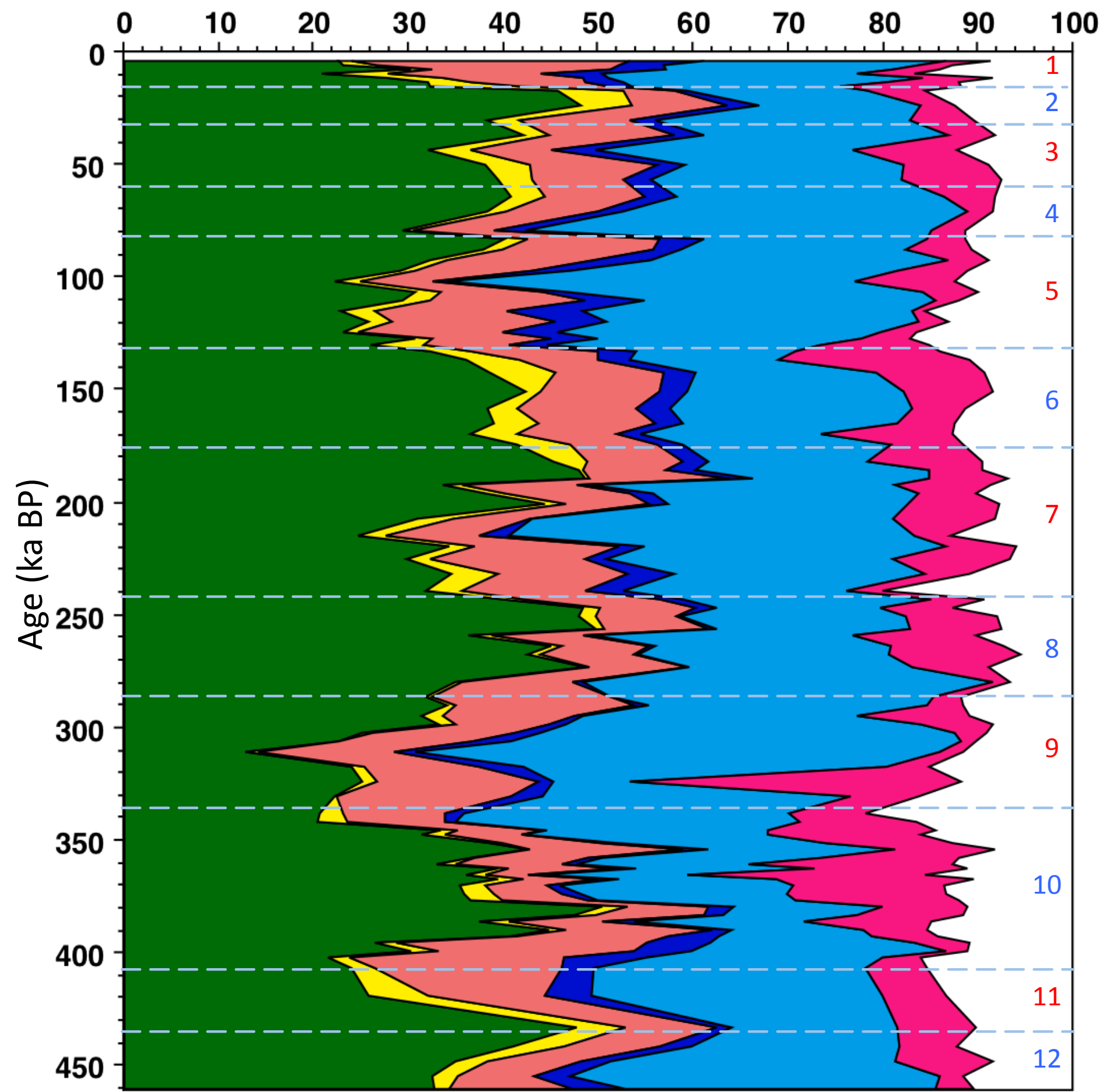

$\square \%$ N. pachyderma sin
$\square \%$ N. pachyderma dex
$\square \%$ G. truncatulinoides
$\square \%$ G. inflata
$\square \%$ G. quinqueloba
$\square \%$ G. bulloides




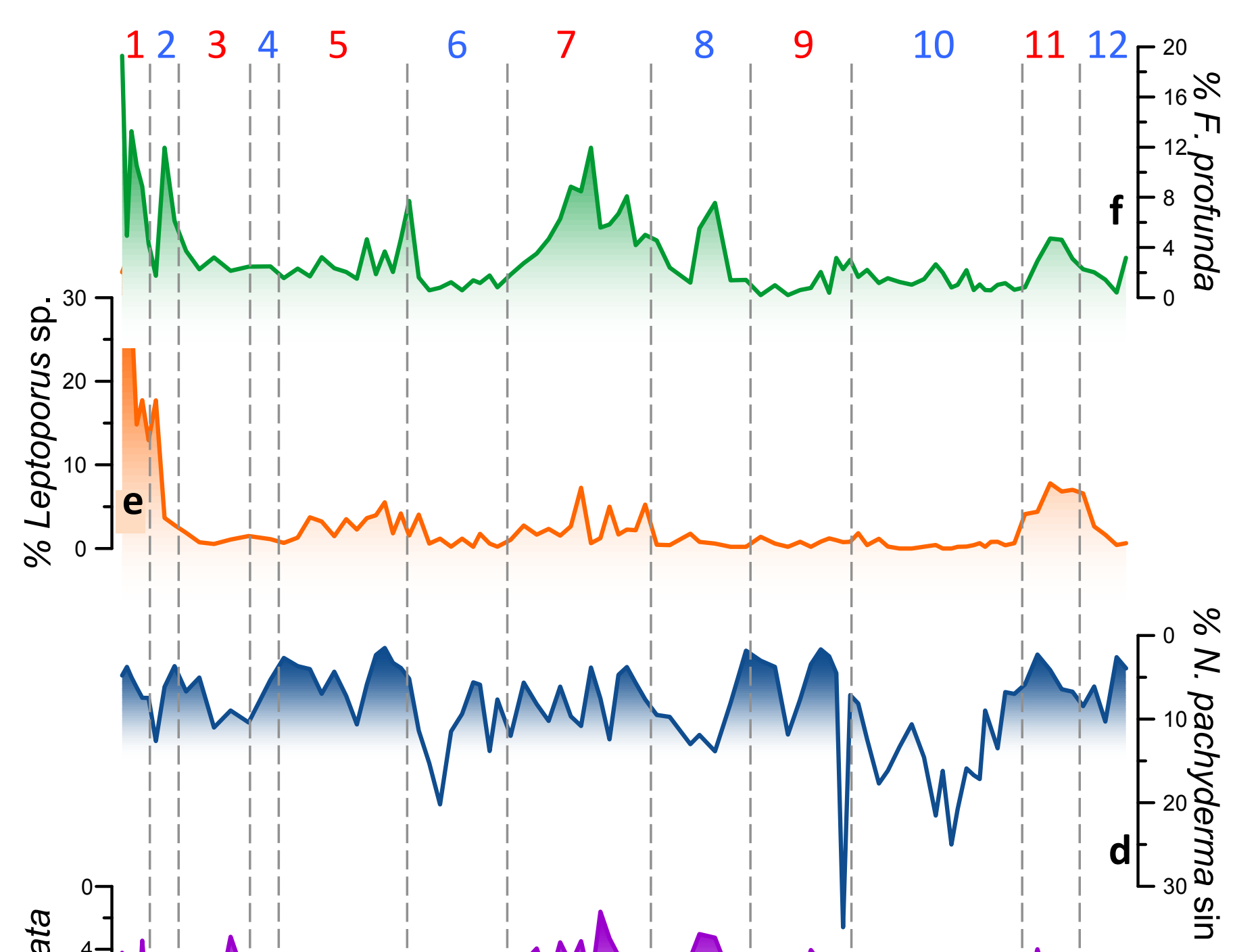


Key abundant coccolith species $\%$

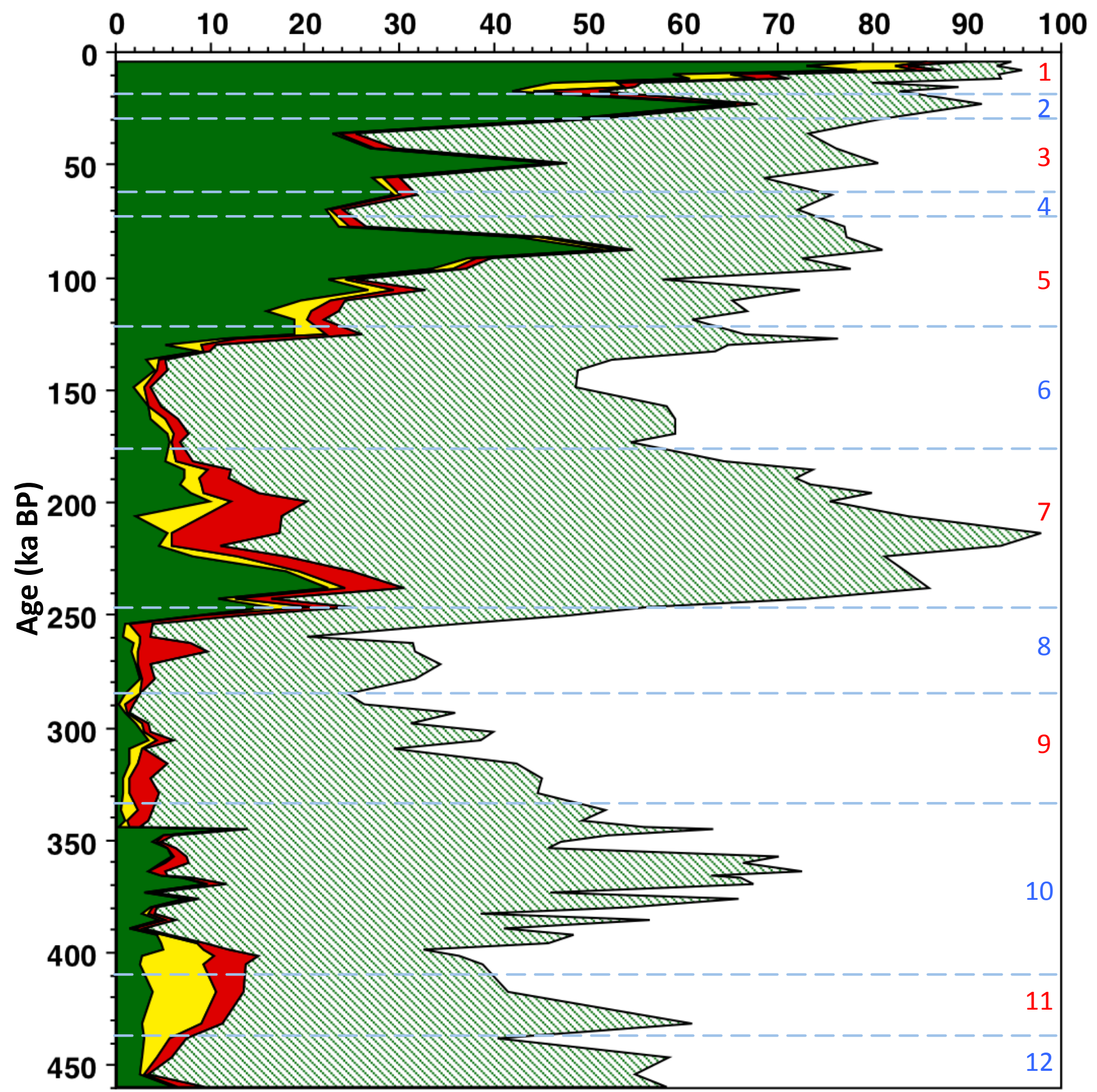

\begin{tabular}{|l|}
\hline \% Gephyrocapsa spp + placoliths \\
$\square \%$ F. profunda \\
$\square \%$ C. leptoporus \\
$\square \%$ E. huxleyi \\
\hline
\end{tabular}




\section{Vegetation types \%}

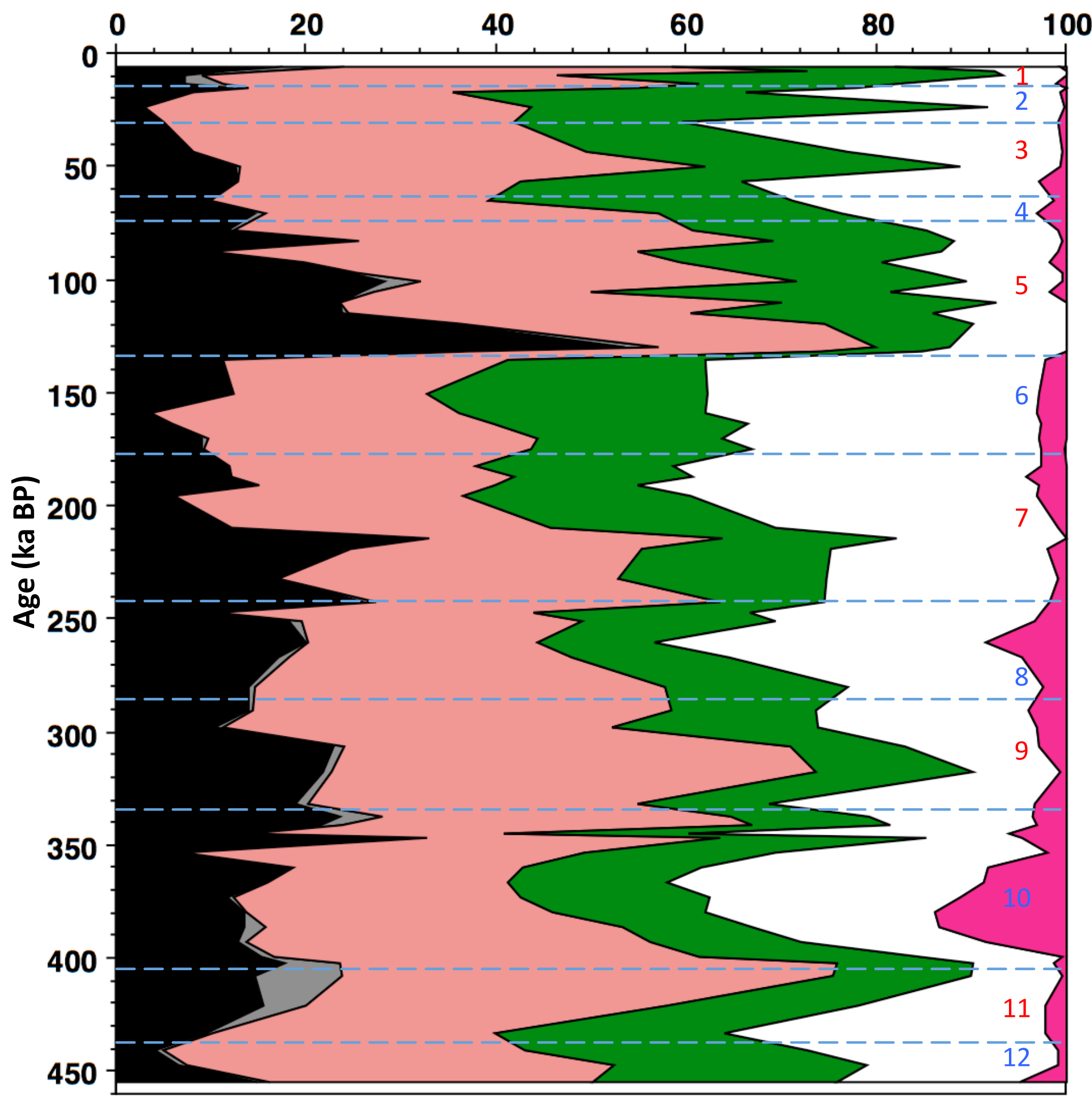

\begin{tabular}{|l|}
\hline$\square$ Alpine taxa \\
$\square$ Herbs \\
$\square$ Sclerophyll shrub-herbs \\
$\square$ Sclerophyll forest \\
$\square$ Wet sclerophyll forest \\
$\square$ Rainforest
\end{tabular}




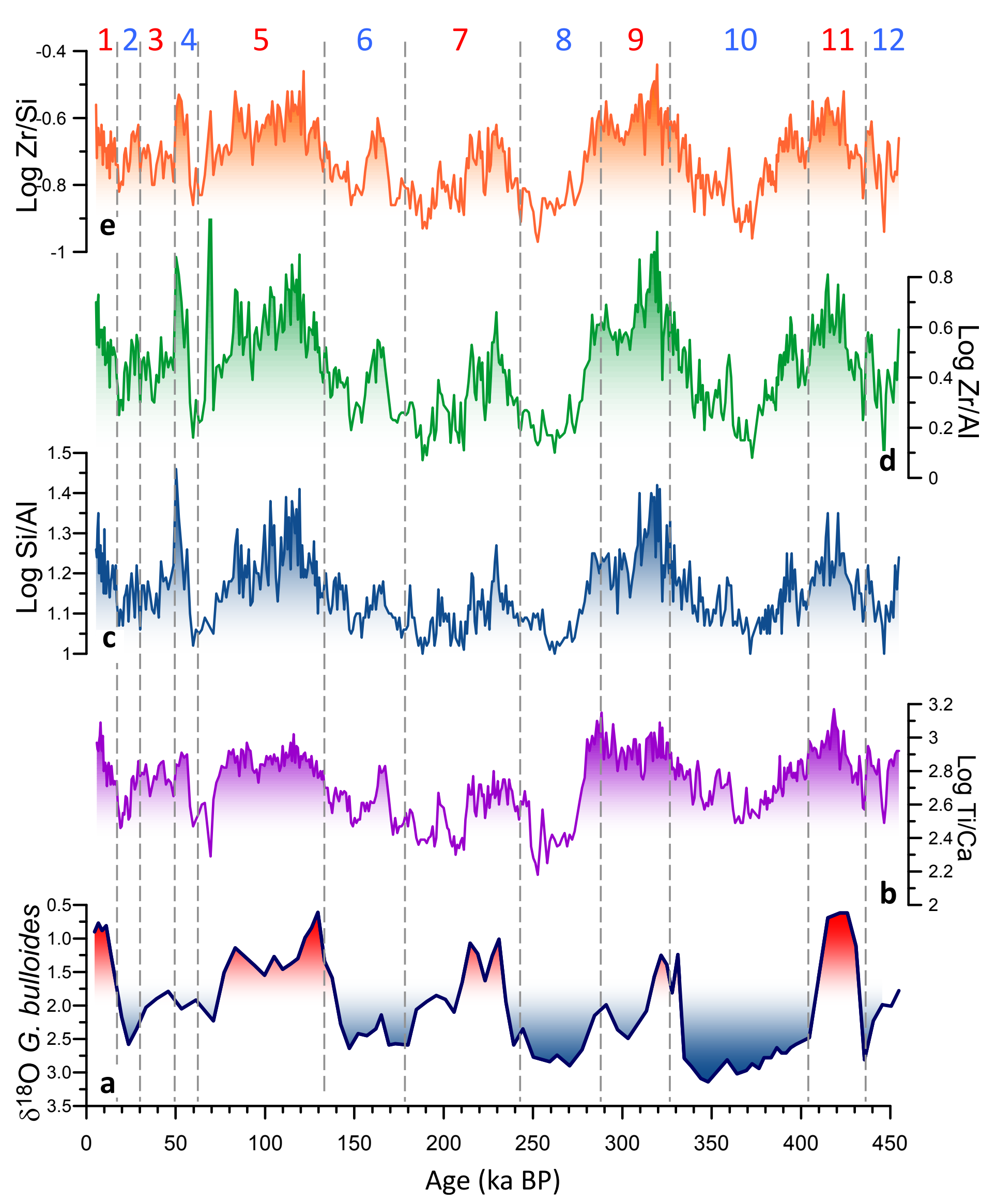


12345

6

7

8

9

$101112^{6}$

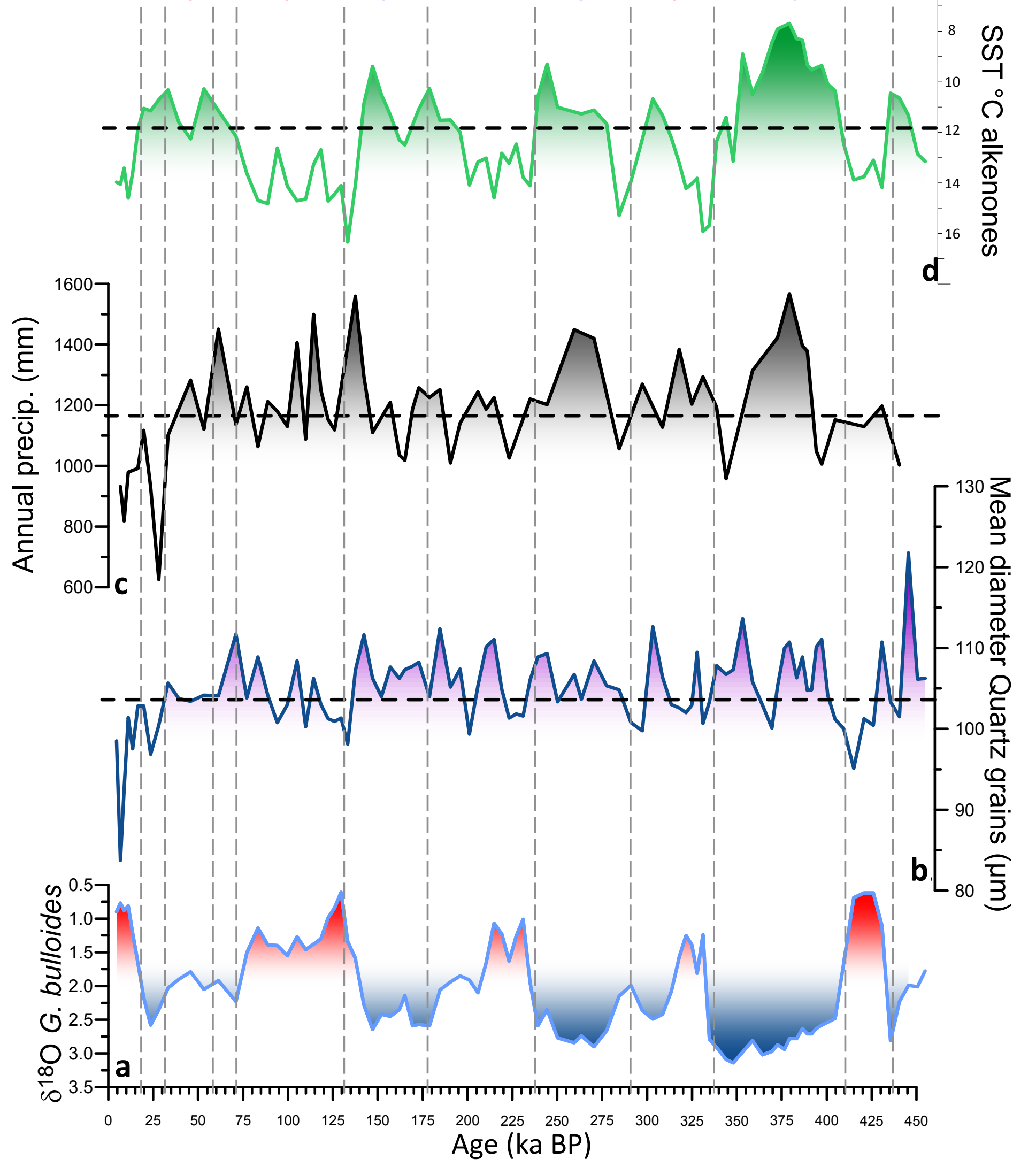




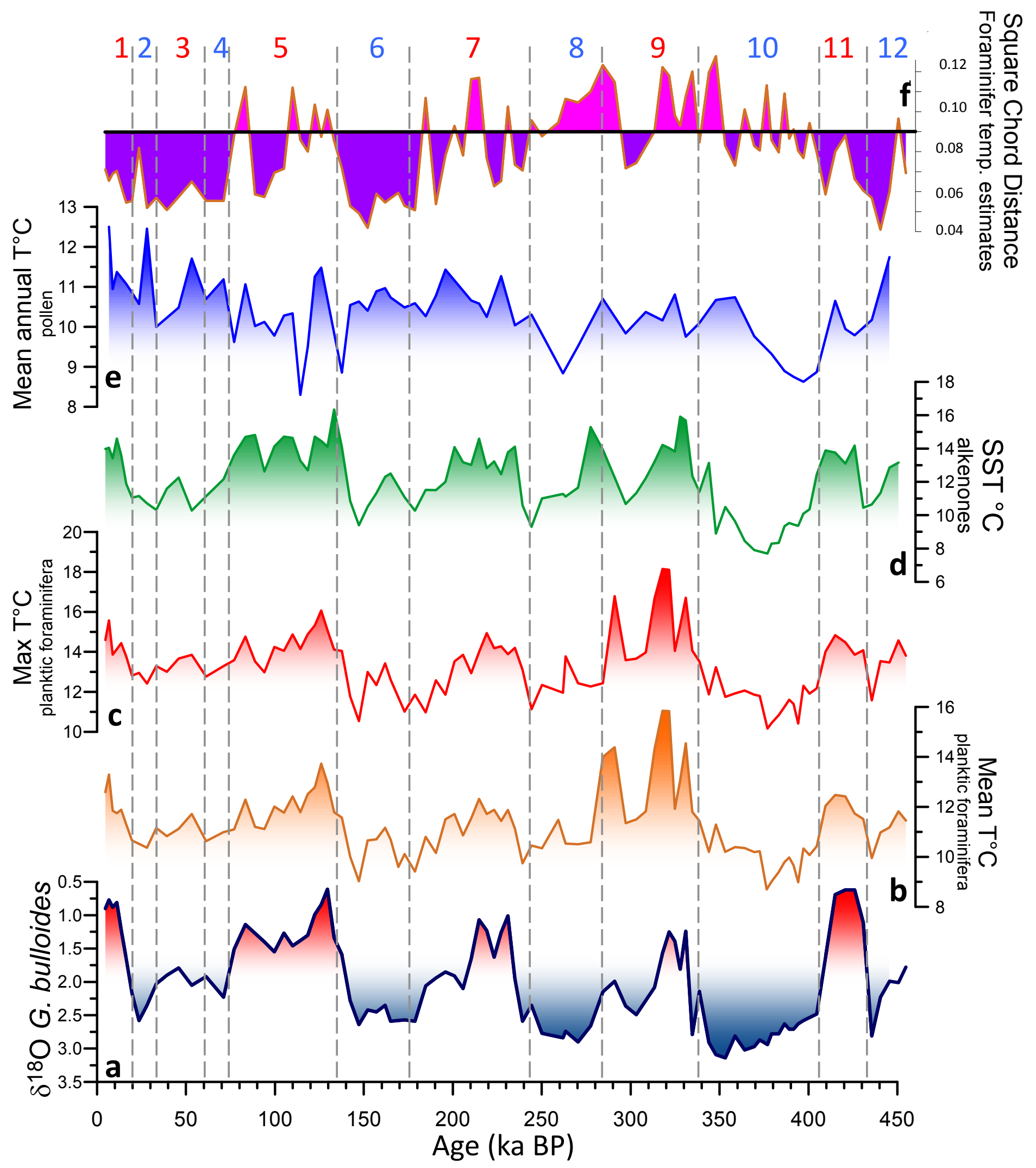


